

OAK

RIDGE

NATIONAL

LABORATORY





ORNL/TM-7152

\section{Overview of the Effects of the Coal Fuel Cycle on Hydrology, Water Quality and Use, and Aquatic Ecology}

\author{
R. M. Cushman \\ S. B. Gough \\ M. S. Moran
}

ENVIRONMENTAL SCIENCES DIVISION

Publication No. 1431
OPERATED BY

UNION CARBIDE CORPORATION FOR THE UNITED STATES DEPARTMENT OF ENERGY 


\section{DISCLAIMER}

This report was prepared as an account of work sponsored by an agency of the United States Government. Neither the United States Government nor any agency Thereof, nor any of their employees, makes any warranty, express or implied, or assumes any legal liability or responsibility for the accuracy, completeness, or usefulness of any information, apparatus, product, or process disclosed, or represents that its use would not infringe privately owned rights. Reference herein to any specific commercial product, process, or service by trade name, trademark, manufacturer, or otherwise does not necessarily constitute or imply its endorsement, recommendation, or favoring by the United States Government or any agency thereof. The views and opinions of authors expressed herein do not necessarily state or reflect those of the United States Government or any agency thereof. 


\section{DISCLAIMER}

Portions of this document may be illegible in electronic image products. Images are produced from the best available original document. 
Printed in the United States of America. Available from National Technical Information Service

U.S. Department of Commerce

5285 Port Royal Road, Springfield, Virginia 22161

NTIS price codes-Printed Copy: A04; Microfiche A01

This report was prepared as an account of work sponsored by an agency of the United States Government. Neither the United States Government nor any agency thereof, nor any of their employees, makes any warranty, express or implied, or assumes any legal liability or responsibility for the accuracy, completeness, or usefulness of any information, apparatus, product, or process disclosed, or represents that its use would not infringe privately owned rights. Reference herein to any specific commercial product, process, or service by trade name, trademark, manufacturer, or otherwise, does not necessarily constitute or imply its endorsement, recommendation, or favoring by the United States Government or any agency thereof. The views and opinions of authors expressed herein do not necessarily state or reflect those of the United States Government or any agency thereof. 
Contract No. W-7405-eng-26

OVERVIEW OF THE EFFECTS OF THE COAL FUEL CYCLE ON HYDROLOGY, WATER QUALITY AND USE, AND AQUATIC ECOLOGY

R. M. Cushman, S. B. Gough, and M. S. Moran

ENVIRONMENTAL SCIENCES DIVISION

Publication No. 1431

Date Published: May 1980

NOTICE This document contains information of a preliminary nature. It is subject to revision or correction and therafore does not represent a final report.

OAK RIDGE NATIONAL LABORATORY

Oak Ridge, Tennessee 37830

operated by

UNION CARBIDE CORPORATION

for the

DEPAR TMENT OF ENERGY 


\section{THIS PAGE}

\section{WAS INTENTIONALLY}

\section{LEFT BLANK}




\section{ACKNOWLEDGMENTS}

The authors would like to thank S. G. Hildebrand, D. D. Huff, and L. W. Barnthouse, Environmental Sciences Division, and E. K. Triegel and J. E. Dobson, Energy Division, for their critical review and suggestions for improvement of this manuscript. 


\section{THIS PAGE}

\section{WAS INTENTIONALLY}

\section{LEFT BLANK}


R. M. CUSHMAN, S. B. GOUGH, and M. S. MORAN. 1980. Overview of the effects of the coal fuel cycle on hydrology, water quality and use, and aquatic ecology. ORNL/TM-7152. Oak Ridge National Laboratory, Oak Ridge, Tennessee. 62 pp.

Literature is sumarized for the effects of the coal fuel cycle (mining, mine-site processing, transportation, storage, onsite processing, combustion, and waste collection and disposal) on water resources. Aspects considered include surface- and ground-water hydrology, water quality and use, and aquatic ecology. Water use is discussed with regard to both availability and water quality constraints on use. Requirements of the recently enacted Surface Mining Control and Reclamation Act are introduced where appropriate. For the combustion step in the fuel cycle, only those effects which are specific to coal as a fuel are addressed. Effects not specific to coal use (such as thermal effects, impingement, and entrainment resulting from cooling water withdrawal and use) are not considered. Reference is made to more exhaustive studies of the topics reviewed. A summary of the major environmental effects of the coal fuel cycle is given be low.

Coal mining and mine-site processing may alter surface and ground-water hydrologic regimes. Such activities may also adversely affect water quality as a result of acidification, mineralization, and sedimentation. Coal transportation may affect water quality through sedimentation from railroad, barge, truck, and conveyor systems; from spills and leaching; and from slurry pipeline dewatering disposal. Coal transportation via slurry pipelines may affect water use as a result of high consumptive demand. Effects of coal storage and onsite processing are seen as similar to, although of lesser magnitude than, the effects of mining and mine-site processing. Coal combustion effects on water quality may result from acid precipitation and trace substance deposition. Waste collection and disposal may affect water quality as a result of runoff, spills, overflow, and leaching of ash and scrubber sludges. In addition to effects caused by consumption of 
water and hydrologic changes, some water uses may be affected by changes in water quality. Aquatic biota may be affected by hydrologic changes and habitat. destruction from mining, and by water quality changes imposed by the entire coal fuel cycle. 
ABSTRACT ........................ . . $v$

LIST OF TABLES . . . . . . . . . . . . . . . . ix

LIST OF FIGURES ... . . . . . . . . . . . . . . . . ix



1. Mining and Mine-Site Processing . . . . . . . . . . 2

1.1 Hydrology ................... 2

1.2 Hydrological Effects on Biota . . . . . . . . 6

1.3 Water Quality.............. 6

1.4 Water Quality Effects on Biota . . . . . . . . 19

1.5 Water Use . . . . . . . . . . . . . 23

2. Transportation . . . . . . . . . . . . . . 27

2.1 Water Quality. ............... 27

2.2 Aquatic Biota . . . . . . . . . . . . 29

2.3 Water Use ................. 29

3. Storage and Onsite Processing ............ . . 31

3.1 Water Quality . . . . . . . . . . . . 31

3.2 Aquatic Biota . . . . . . . . . . . . 31

3.3 Water Use .................. . 33



4.1 Water Quality.............. 34

4.2 Aquatic Biota . . . . . . . . . . . 36

4.3 Water Use . . . . . . . . . . . . . 38 


\section{Page}

5. Waste Collection and Disposal . . . . . . . . . 39

5.1 Water Quality . . . . . . . . . . . . 39

5.2 Aquatic Biota................ 43

5.3 Water Use ........................... 44

REFERENCES ........................ 45 


\section{LIST OF TABLES}

Table

Page

1 Representative water quality measurements for coal mine and refuse effluents ................

2 Selected federal water quality criteria for drinking water, irrigation, livestock watering, and protection of



3 Representative water quality measurements for coal pile leachate and coal pile drainage ......... 32

4 Representative water quality measurements for coal waste disposal effluents...............

1 Map of the conterminous United States showing federal regions and water resource regions........... 


\section{IN TRODUCTION}

This document is an analys is of the literature on the effects of the coal fuel cycle on surface- and ground-water hydrology, water quality and use, and aquatic ecology. The effects of coal mining and mine-site processing, transportation, storage and onsite processing, combustion, and waste collection and disposal are discussed. Combustion effects are limited in this document to those specific to coal fuels; effects not specific to coal use, such as thermal effects, impingement, and entrainment resulting from cooling water withdrawal and use, are not considered. Since this is an overview, reference is made to more exhaustive studies of particular aspects of environmental effects. Portions of this manuscript were developed in conjunction with the preparation of the Final Environmental Impact Statement for the Fuel Use Act (U.S. DOE 1979). 
ORNL/TM-7152

\section{MINING AND MINE-SITE PROCESSING}

\subsection{HYDROLOGY}

Mining and mine-site processing have historically affected both surface- and ground-water hydrology. The National Strip Mine Study provides an overview of hydrologic effects of surface and underground mining of coal and other minerals (U.S. Army Corps of Engineers 1974).

Coal mining has been observed to alter the volume and rate of surface-water runof $\bar{f}$, which is, of course, interrelated with ground-water hydrolingy (U.S. Army Corps of Engincers 1974), In steep-sloped coal areas of eastern Kentucky, storm runoff was more rapid in watersheds where at least $10 \%$ of the land was disturbed by contour stripping. Because storm runoff is accelerated when vegetation is lacking, reclamation is obviously an important determining factor. The reduced runoff-carrying capacity of streams with higher sediment loads has increased flood damages (U.S. Army Corps of Engineers 1974). Increased flood peak stage as a result of coal mining has been seen as particularly hazardous in southern Appalachia (Kash et al. 1977). Thus, eastern Kentucky has experienced a flooding hazard berause of runoff and erosion from waste embankments and overburden slopes. On the other hand, reductions in flooding have been attributed to storage in last-cut impoundments (final basin remaining at end of surface mining operation) and overburden piles (U.S. Army Corps of Engineers 1974, Curtis 1977).

Surface waters may disappear if their flow is intercepted by induced fractures or subsidence, a particular hazard of underground mining in Federal Regions III, IV, and V (see Fig. 1), with resulting flow into the mines (Hill and Bates 1977). Surface waters may also be created in the mining process, not only by last-cut impoundments (Doyle 1976) but also by swamping. Swampy conditions may be created by large, area-strip mines and sediment-blocked channels in flat, poorly drained landscape (U.S. Army Corps of Engineers 1974). Changes in natural drainage patterns caused by subsidence may also form swamps ( $\mathrm{Hill}$ and Bates 1977). The potential formation of extensive closed drainage 




Fig. 1. Map of the conterminous United States showing federal regions and water resource regions. (Modified from U.S. Geological Survey, 1977, Estimated use of water in the United States in 1975, Circular 765, Arlington. Virginia.) 
basins in the Gillette, Wyoming, area has been described as a result of surface mining for coal (Keefer and Hadley 1976). Although the climate is not particularly conducive to swamp development, induced local recharge to ground water is accelerated.

The existing subsurface hydrologic environment can be affected by mining and mine-site processing in numerous ways. Depending on the geographic location, the topography, the nature of the overburden, and the underlying geology, the flow regime can be adversely or beneficially al tered.

Dry-weathar flow in sinall streams may be decreased or increased (U.S. Army Corps of Engineers 1974, Minear and Tschantz 19/6). Increased dry-weather flow in western Kentucky has been attributed to storage in last-cut impoundments and overburden piles (U.S. Army Corps of Engineers 1974), while the same effect noted in small watersheds of the New River Basin of the Ohio Water Resource Region (see Fig. 1) resulted from the gradual release of stored spoil-bank seepage and bench impoundment (Minear and Tschantz 1976).

Last-cut impoundments, overburden piles, spoil banks, and benches are more permeable than the underlying bedrock (Moid U. Ahmad, Ohio University, personal communication). The gradual release to a stream of water stored in this material could aller the stream's low-flow characteristics In several ways. First, the frequencies of low-flow discharges would increase; second, a given low flow (ground-water contribution) of a stream could be expected to be sustained for a longer period of time. Springflows could also be increased. or sustained. Water stored in the pile-and-bank material would create local high-head mounds in the ground-water body's potentiometric surface (the actual or pulential watcr level within a we11). Depths to water would be correspondingly decreased, possibly causing the water table to intersect the land surface, forming swamps or seeps. Flow directions would be altered from those existing prior to mining and mine-site processing, with possiblc downgradient movement of ground water in directions opposite to previous ones. Ground water could, under these conditions, move locally away from a nearby stream, contributing to the flow at another reach of the stream, entering a 
different stream, or exiting the basin by underflow entirely. These storage effects would be more pronounced in areas of gradual slope underlain by unconsolidated rock material or bedrock that is low in clay content (i.e., more permeable), such as the Texas-Gulf Coast region.

Steeply sloped areas with large amounts of rainfall (>1000 m/year) and consolidated bedrock, such as Appalachia, are characterized by flashy streams (streams which exhibit rapid and extreme flow responses to precipitation events, as distinguished from streams where flow response to precipitation events is moderated by interaction with ground-water storage). The residuum in such areas is thinner and typically less permeable, being weathered from clayey sandstones and carbonaceous shales. Mining and mine-site processing in this more rugged topographic area could in some instances reduce recharge to the ground-water systems (J. Van Brahana, U. S. Geological Survey, personal comunication). Slopes locally steepened by mining activities would compound the existing rapid runoff problems. Consequently, flood peak stages of smaller tributaries could increase. Reduction in recharge would ultimately result in the decrease of sustained low flows of nearby streams. Spring discharges could also decrease and could cease flowing at times when flow would ordinarily be expected.

Ground-water flow regimes could also be altered by mine pumpage and/or subsidence. Pumpage would depress the potentiometric surface (the actual or potential water level within a well) locally, inducing or pirating flow from adjacent areas, which could possibly deplete nearby well fields and streams. Subsidence in underground mining areas could occur, inducing interior drainage and ground-water recharge. Mining in the western United States has also exposed ground-water aquifers to the surface (Kash et al. 1977).

In accordance with the Surface Mining Control and Reclamation Act of 1977, hydrologic effects of surface and underground mining are to be controlled. Features of the hydrologic system to be protected include depth to ground-water, location of surface-water drainage channels, flow regimes, and ground-water recharge capacity (Office of Surface Mining Reclamation and Enforcement 1979). The extent to which 
appropriate federal and state regulations are applied and enforced will determine the extent to which the potential hydrologic effects described in this section are realized or prevented.

\subsection{HYOROLOGICAL EFFECTS ON BIOTA}

Hydrological effects that can occur as a result of coal mining are listed in Section 1.1. Altered flow regimes can be highly disruptive to stream communities (Hynes 1971). Drawdown can result in the loss of habitat, and greater flows can produce bottom and edge scouring, thus resulting in fewer benthic organisms, less autochthonous food for higher organisms, and higher turbidities from the suspended substrate material (see Section 1.4 for turbidity and sedimentation impacts). The loss of surface waters obviously constitutes a loss of habitat for the biota, and the creation of surface water (e.g., impoundments from last-cuts in strip mining) provides new areas for biotic colonization. Newly created habitats may only offer highly stressed conditions, however, because the water may have high concentrations of heavy metals, acids, and sulfates.

\subsection{WATER QUALITY}

Surface-water quality effects from codl mining and mine-site processing may be grouped broadly into acid drainage, other dissolved constituents (alkaline drainage, trace substances), and increased suspended solids loads. Several works contain a more thorough discussion of coal mining and processing effects on water quality (Appalachian Regional Commission 1969, U.S. Army Corps of Engineers 1974, Hill and Bates 1977, Dvorak et al. 1977, Davis et al. 1978, Martin 1976, Minear and Tschantz 1976). Van Hook (1978) addresses current knowledge of mobilization of trace substances from coal mining and processing.

Acid drainage is a consequence of the oxidation of sulfur-bearing materials within coal or disturbed overburden. In areas of high-sulfur coal, such as in parts of Appalachia, pyrite and marcasite are the main sulfide minerals. During the leaching process, these iron disulfides undergo oxidation to a series of hydrous iron sulfates. Acid mine 
drainage results when the iron sulfates come in contact with water, generating large amounts of iron and sulfate. Determining factors (as with other water chemistry aspects) include contact time of water with the sulfide minerals; redox potential; hydrologic, geologic, and topographic features of the mine and surrounding terrain; type of mine operation; and active or inactive status of the mining (U.S. Army Corps of Engineers 1974). The amount of pyrite and marcasite present in the coals and associated rock formations is not necessarily proportional to the potential acid generated. Several modes of iron disulfide are commonly present in coal strata: marcasite, primary framboidal reactive pyrite, primary euhedral pyrite, and secondary inert pyrite. The role of microorganisms (bacteria) in the oxidation of reduced sulfur compounds and of $\mathrm{Fe}^{+2}$ to $\mathrm{Fe}^{+3}$ is under debate ( $\mathrm{Hill}$ and Bates 1977). Associated with acid drainage are elevated levels of trace substances, including heavy metals ( $\mathrm{Hill}$ and Bates 1977, Cairns et al. 1971). In general, abandoned underground mines have been the primary source of acid drainage, although surface mining and refuse (gob and slurry) contribute appreciable quantities in certain areas (U.S. Army Corps of Engineers 1974; Martin 1974b, 1976; Hill and Bates 1977; Minear and Tschantz 1976; Tomkiewicz and Dunson 1977; Dvorak et al. 1977). Inactive deep mines are seen as not only the greatest problem but also the least controllable because of the inadequacy of control technology (Hill and Bates 1977; U.S. DHEW 1978).

The effects of mine-site coal processing are similar to those of mining, although of lesser magnitude. Air and water can easily enter refuse piles, with resulting acidity. Processing and refuse effluents have been estimated to contribute $7.5 \%$ of the acid drainage in Appalachia (Dvorak et al. 1977). The acid drainage from coal refuse has been described for Eastern Interior and Appalachian areas (Martin 1974 a, 1974b, 1976).

Acid mine drainage typically exhibits the following characteristics (Cairns et al. 1971): 
$\mathrm{pH}$

Acidity

Alkalinity

Alkal in ity/acidity

$\mathrm{Fe}$

$\mathrm{SO}_{4}$

Total suspended solids (TSS)

Total dissolved solids (TDS)

Total hardness
$<6.0$

$>3 \mathrm{mg} / 1$ iter

$0 \mathrm{mg} / \mathrm{liter}$, normally

$<1.0$

$>0.5 \mathrm{mg} / 7$ iter

$>250 \mathrm{mg} / 7$ iter

$>250 \mathrm{mg} / \mathrm{liter}$

$>500 \mathrm{mg} / \mathrm{Titer}$

$>250 \mathrm{mg} / 1$ iter

Water quality measurements for acid mine and refuse effluents for a variety of coal mining areas are given in Table 1. Streams in Indiana and Illinois have had $\mathrm{pH}$ levels reduced by 4 to 5 units, with a change from net alkalinity to net acidity (Martin 1974b).

For comparison, selected water quality criteria for drinking water, irrigation, livestock watering, and protection of aquatic biota are presented in Table 2. This table, however, is incomplete: standards and criteria exist for other parameters and other uses. Additionally, state standards and criteria, in accordance with the Federal Water Pollution Control Act, may be more stringent than those that have been federally promulgated. Nevertheless, the tabulated criteria provide a useful basis for comparison. Characteristically, acid drainage exceeds many of the standards and criteria for drinking water, protection of aquatic biota, and other uses. We emphasize that reported data are frequently not specified to be of either dissolved or total concentrations; the latter values may be considerably higher in the same sample. In accordance with the Surface Mining Control and Reclamation Act of 1977, discharges from surface and underground mining operations must have a pH of between 6.0 and 9.0 (Office of Surface Mining Reclamation and Enforcement 1979).

The full impact of acid drainage from new mines is not felt until atter the ir closure (Hill and Bates 1977). The acidity problem with self-draining underground mines, as well as with auger mines and refuse banks with high pyritic concentrations, continues for an indefinite time (U.S. Army Corps of Engineers 1974). For example, in the New 
Table 1. Represertative water quality measurements for coal mine and refuse effluents (all values except pH expressed as $\mathrm{mg} / \mathrm{liter}$ [ppm])



aTypical acid'mine drainage. From $\mathrm{Hill}$ and Bates (1977).

bAcid mine drainage vater. From Kopp and K-oner (1967).

cComposite Appalachian mine effluent; lime-neutralized; ISS, Fe, and Mn assumed adjusted to meet effluent limitations. From Dvorak et al. (1977).

dComposite northern Great Plains mine effluent; untreated, except TSS assumed adjusted to meet effluent limitations. From Dvorak et al. (1977).

eRefuse effluent, northeastern Penrisylvania. From Martin (1974a).

fRefuse effluent, eastern Kentucky. From Martin (1974a).

GRefuse effluent, western Kentucky. From Martin (1974a).

$h_{R e f u s e}$ effluent, southwestern Indiana. From Martin (1974a).

iRefuse efflueit, southern Illinois. From Martin (1974b).

JRefuse effluent, wes:ern Pennsylvanic. Fron Martin (1974b).



'Refuse effluerit, southern West Virginia. From Martin (1974b). 
Table 2. Selected federal water quality criteria for drinking water, irrigation, livestock watering, and protection of aquatic biota (all values except $\mathrm{pH}$ expressed as $\mathrm{mg} / 1$ iter $[\mathrm{ppm}]$ )

\begin{tabular}{lllll}
\hline Drinking & $\begin{array}{c}\text { Recommended } \\
\text { water } \\
\text { standard }\end{array}$ & $\begin{array}{c}\text { Recommended } \\
\text { water limition } \\
\text { water }\end{array}$ & $\begin{array}{c}\text { Aquatic biota } \\
\text { wrotection } \\
\text { wimit }\end{array}$ \\
\hline
\end{tabular}

\begin{tabular}{|c|c|c|c|c|}
\hline $\begin{array}{l}\text { Al } \\
\text { As } \\
B \\
\text { Ba } \\
\text { Cd } \\
\\
\text { Co } \\
\text { Cr } \\
\text { Cu } \\
\text { Fe } \\
\text { Hg } \\
\text { Mn } \\
\text { Ni } \\
\text { Pb } \\
\text { Se } \\
\text { V } \\
\text { Zn } \\
\text { SOA } \\
\text { Alkalinity } \\
\text { Total dissolyed } \\
\text { solids (ToS) } \\
\text { pH }\end{array}$ & $\begin{array}{l}0.05^{d} \\
1^{f} \\
0.3^{f} \\
0.002^{d} \\
0.05^{f} \\
0.05^{d} \\
0.01^{d}\end{array}$ & $\begin{array}{l}5.0 \\
0.10 \\
0.75 \\
0.010 \\
\\
\\
0.050 \\
0.10 \\
0.20 \\
5.0 \\
0.20 \\
0.20 \\
5.0 \\
0.020 \\
0.10 \\
? .0 \\
\end{array}$ & $\begin{array}{l}5 \\
0.2 \\
5 \\
0.050\end{array}$ & $\begin{array}{l}0.1^{\mathrm{c}} \\
0.3^{\mathrm{c}} \\
392^{\mathrm{c}} \\
104^{\mathrm{c}} \\
0.0010 .004 \\
(\text { soft })^{\mathrm{e}} \\
0.0012-0.0120 \\
\left(\text { hard } \mathrm{e}^{\mathrm{e}}\right. \\
6.25^{\mathrm{c}} \\
0.100^{\mathrm{e}} \\
0.0009^{\mathrm{g}} \\
1 . \mathrm{e}^{\mathrm{g}} \\
0.00005^{\mathrm{e}} \\
0.35^{\mathrm{e}} \\
0.0159 \\
0.003^{9} \\
0.02^{\mathrm{g}} \\
4.8^{\mathrm{c}} \\
0.0004 \mathrm{~g} \\
>20 \mathrm{e} \\
\\
6.5-9.0^{\mathrm{e}}\end{array}$ \\
\hline
\end{tabular}

afor waters used continuously on all soil. From National Academy of Sciences and National Ar.ademy of Engineering (1973).

bNational Academy of Sciences and National Academy of Engineering (1973).

CLowest concentration lethal to fish. From Cushman et al. (1977).

dFrom U.3. [nvidronmenlà 1 Protection Agency (1975).

eFrom U.S. Environmental Protection Agency (1976).

fFrom U.S. Environmental Protection Agency (1977b).

GApplication factor recomended in reference (e) multiplied by the lowest concentration reported as the $96-\mathrm{hr} \mathrm{LC}_{50}$, the concentration lethal to $50 \%$ of the test organisms in $96 \mathrm{hr}$, in Cushman et al. (1977). 
River Basin (Ohio Water Resource Region), abandoned underground mines, even though sealed, were found to be important acid sources (Minear and Tschantz 1976). Area and contour strip mines typically produce more early acidity than deep mines; however, total acidity is less, acidity is more controllable, and some neutralization occurs during the mixing of strata (U.S. Army Corps of Engineers 1974). The presence of calcareous soils and formations limits the acid problem in some areas (U.S. Army Corps of Engineers 1974). Neutralization of acidity by alkaline earth compounds in mine spoils, soils, and water bodies; by adsorption to clays; and by reaction with alkaline surface and ground waters is a factor (Dvorak et al. 1977). However, when neutralization occurs from overburden alkalinity, high sulfate concentrations may still be a problem. For example, northwestern Pennsylvania coal fields capped by calcareous glacial drift generate neutral, although high-sulfate, mine drainage. Even after treatment of acidity, high dissolved solids and hardness may limit domestic and industrial uses ( $\mathrm{Hill}$ and Bates 1977). Also, after neutralization, concentrations of iron, aluminum, manganese, and zinc may still range from 1 to $10 \mathrm{ppm}$ in dissolved or colloidal form, and iron and aluminum, when neutralized, form flocculant precipitates (Dvorak et al. 1977). The covering of waste piles with nontoxic soil materials has been effective in mitigating acidity problems (Martin 1974b).

Ground-water quality problems associated with mining and mine-site processing result primarily from the leaching of spoils in stripped areas and of material in undergrourid mines. Ground waters may exhibit reduced or increased $\mathrm{pH}$, increased TDS (with increased concentrations of most elemental and compound components), production of ammonia and hydrogen sulfide, and contamination by hydrocarbons.

The leaching of strip mine spoils and underground mine material produces initially localized effects in the ground-water system. Given high transmissivities, these could affect entire aquifers. Ultimately, the local degradation or contamination of ground water can be areally extensive. Ground-water movement can be quite rapid, up to hundreds of meters per year. This rapid ground-water movement, associated with interaquifer flow, can spread ground-water degradation over a large 
volume of aquifer material. Areas of calcareous material in, or constituting, bedrock are important. Ground waters in these strata, which have a pH (before mining) greater than 6.4, can neutralize minor amounts of acidity by their alkalinity. Additionally, iron bacteria (Section 1.4) are not supported in this environment, and the acid reaction is not catalyzed.

The alkalinity and $\mathrm{pH}$ of infiltrating water can be controlled, at least partially, during reclamation. Alkaline chemical compounds or calcareous rock material could be spread over spoil banks or backfilled into mine areas. An alkaline front could thus be formed that: would mnve with perculdling ground water, displacing iron bacteria before any ground-water acid problems could occur.

The results of surface mining in the New River Basin (Ohio Water Resource Region), which included a rise in both $\mathrm{pH}$ and alkalinity in small watershed streams, were similar to those of other studies in West Virginia. Increased variability in these parameters was also described. Water-material contact was promoted by unconsolidated spoils (Minear and Tschantz 1976).

The effect of stream flow on dilution and assimilation of mine drainage is important. Reduction in the dry-weather (low) flow of small streams may exacerbate ac id drainage effects (U.S. Army Corps of Engineers 1974). In the New River Basin (Ohio Water Resource Region), it was found that when flow was lowest, $\mathrm{pH}$ in affected streams also fell, with resulting destruction of stream alkalinity and severe $\mathrm{pH}$ oscillations (Minear and Tschantz 1976). Conversely, in some Appalachian areas, the major production of mine acidity is in winter and spring, when higher flows (and lower temperatures) limit adverse effects (U.S. Army Corps of Engineers 1974).

Acid mine drainage and its effects have been described for the Mid-Atlantic Water Resource Region (abandoned deep mines and, secondarily, surface mines in the Delaware, Potomac, and Susquehanna River Basins) and for the South Atlantic-Gulf Water Resource Region (abandoned strip mines in the Tombigbee-Black Warrior Basin) (U.S. Army Corps of Engineers 1974). The Ohio Water Resource Region is the most affected region, with acid drainage being a serious problem in the 
Allegheny, Monongahela, and Ohio River watersheds of the upper basin; in the Green, Tradewater, Saline, and Wabash watersheds of the lower basin; and in certain small tributary systems of the middle basin. The Tennessee Water Resource Region, the Upper Mississippi Water Resource Region (area stripping in tributaries to the Chariton, Osage, and Missouri Rivers in Missouri) have also experienced acid mine drainage (U.S. Army Corps of Engineers 1974). In the Appalachian area, where many stream reaches are almost constantly acidic, the acid drainage problem (primarily from abandoned deep mines) is the most serious in the northern part because of the absence of calcareous soils (U.S. Army Corps of Engineers 1974, Kash et al. 1977). In southern Appalachia, calcareous formations are widespread, and acid mine problems are more localized (U.S. Army Corps of Engineers 1974). A thorough discussion of the acid mine drainage problem in Appalachia can be found in Appalachian Regional Commission (1969).

Area stripping in Montana, Wyoming, North Dakota, and South Dakota is not a major problem yet, because of low precipitation rates, low sulfur content of coal, remoteness of streams, and state regulations (U.S. Army Corps of Engineers 1974). However, there are exceptions to these regional generalizations. The northern Great Plains are a potential problem area, if high-pyrite coal is mined (Kash et al. 1977); isolated cases of acid mine drainage have been reported from Colorado and Montana. Many large coal areas in Illino is and Kentucky have not. experienced acid drainage problems ( $\mathrm{Hill}$ and Bates 1977).

Alkaline drainage is a problem in the western coal fields (Habegger et al. 1977). There, overburden and deposits between coal seams are characterized by high concentrations of sodium, calcium, magnesium, carbonate, bicarbonate, sulfate (from overburden sulfate rather than from pyrite oxidation as in acid drainage), and chlorine. The dilution potential of many western streams is marginal, because of ephemeral or reduced summer and winter flows (Dvorak et à . 1977).

Reduction of $\mathrm{pH}$ from acid drainage has been associated with increased concentrations of zinc, copper, manganese, calcium, magnesium, and arsenic (Cairns et al. 1971); the solubility of many trace elements is increased at a lower pH. The minerals of copper, 
zinc, aluminum, and manganese are of ten associated with pyrite ( $\mathrm{Hill}$ and Bates 1977). The stable iron disulfides have crystals generally larger than $5 \mu \mathrm{m}$ in diameter and contain trace amounts of titanium. Reactive framboidal pyrite crystals generally are smaller than $0.5 \mu \mathrm{m}$ and contain trace amounts of silver (Caruccio 1975). Elevated levels of boron, in addition to many of the previously mentioned elements, have been found in coal refuse effluents (Martin 1976). Metals and sulfate concentrations in refuse seeps are generally proportional to acidity levels (Martin 1974b). In addition to these elements, cadmium, chromium, cobalt, iron, nickel, lead, and selenium are considered to he of major concern from coal mining (Dvorak et al. 1977).

Coal mining also typically causes total dissolved solids (TDS) increases (Dvorak et a1. 1977, Minear and Tschantz 1976). Total dissolved solids concentrations in ground water would increase as leachate from spoils and mines infiltrates area aquifers. In Federal Regions III, IV, and V, elements and compounds such as iron, manganese, aluminum, zinc, and $\mathrm{SO}_{4}$ are locally increased in concentration (Table 1). In the western coal fields, where ground waters are characteristically alkaline and saline, leaching of salts from spoils could appreciably degrade the ground-water quality of the aquifers. When high TDS levels are encountered, sulfate is often a constituent, but calcium, magnesium, and bicarbonate provide much of the total salinity (Dvorak et al. 1977).

Water quality measurements for mine and refuse effluents for a variety of coal mining areas are presented in Table 1. By comparison with Table 2, it can be seen that many of the concentrations in Table 1 (aluminum, cadmium, cobalt, chromium, copper, iron, mercury, manganese, nickel, lead, zinc, TDS, sulfate, alkalinity, and $\mathrm{pH}$ ) do not meet various water quality criteria.

The reported adverse effects of coal mining and mine-site processing can be attributed mostly to untreated or inadequately treated effluents or discharges. But even the effluent limitations for coal mining and associated activities established by the Office of Surface Mining Reclamation and Enforcement (1979) would allow iron and manganese concentrations exceeding the criteria or standards for 
drinking water, irrigation water, and aquatic biota protection. Thus, dilution by receiving waters is assumed. The aforementioned effluent limitations allow maximum total iron and manganese concentrations of 7.0 and $4.0 \mathrm{mg} /$ liter, respectively; averages of daily values for 30 consecutive discharge days shall not exceed 3.5 and $2.0 \mathrm{mg} / 1$ iter, respectively (iron limits from new sources are $6.0 \mathrm{mg} / 1$ iter and $3.0 \mathrm{mg} / 1$ iter, respectively). Assuming a typical mine effluent flow of 160 liters/s (Dvorak et al. 1977), the following flows (liters/s) of distilled water are required to dilute the maxiumum iron and manganese concentrations to the water quality criteria for drinking water, irrigation water, and protection of aquatic biota.

\begin{tabular}{cccc}
\hline Constituent & $\begin{array}{c}\text { Drinking } \\
\text { water }\end{array}$ & $\begin{array}{c}\text { Irrigation } \\
\text { water }\end{array}$ & $\begin{array}{c}\text { Protection of } \\
\text { aquatic biota }\end{array}$ \\
\hline Iron & 3500 & 62 & 920 \\
Manganese & 12000 & 3000 & 1600 \\
\hline
\end{tabular}

Where more than one mine discharge enters a receiving water, or where there are nonzero background levels of iron or manganese, the dilution requirement would be increased.

In the New River Basin, surface mining caused calcium and magnesium concentrations to increase to such an extent that overall water chemistry changed from soft to hard. Sulfate levels also rose, although they lagged the initiation of mining, and reflected the extent of and time since disturbance. Iron measured in streams exceeded both drinking water and permit standards, while manganese exceeded the drinking water standard. A small fraction of total iron was in the soluble form because of the high $\mathrm{pH}$, and ferric oxide was deposited on the streambed. Constituent concentrations in disturbed watersheds varied with precipitation and flow, wille corresponding parameters were more stable in control (undisturbed) watersheds (Minear and Tschantz 1976 ).

In Appalachia, the greatest production of mine effluent trace substances occurs typically in winter and spring, when stream flow is 
greatest. However, summer storm runoff enters streams during low-flow conditions when dilution capability is also low. The neutralization of acid drainage by calcareous formations in southern Appalachia does not prevent heavy metals from being a downstream problem (U.S. Army Corps of Engineers 1974). Covering of refuse piles with nontoxic soil materials has proven effective in mitigating increased iron levels in the Eastern Interior region (Martin 1974b).

Effluents containing nitrogen and phosphorus used in mining chemicals may accelerate eutrophication, and where eutrophication causes surface walers to become anoxic, nitrate and sulfate may be reduced to ammonia and hydrogen sulfide, respectively (Dvorak et al. 1977). Nitrogen used in minirig chemicals can be reduced to ammonia, which can contaminate an aquifer. Hydrocarbons such as kerosene, used to wash coals, could perhaps locally contaminate ground waters, a.l though not likely to any appreciable extent.

The National Strip Mine Study (U.S. Army Corps of Engineers 1974) contains an overview of the effects of sedimentation on aquatic resources. The magnitude of sedimentation is related to the land area disturbed, but sedimentation alsu results from coal processing runoff and spills (U.S. Army Corps of Engineers 1974, Dvorak et al. 1977). Spills of slurry have discharged coal fincs and silt into eastern and midwestern streams (Dvorak et al. 1977). Coal refuse effluents may have suspended solids levels ranging into the thousands of milligrams per liter (Martin 1976). Stream sediment loads in disturbed watersheds of the New River Basin not only increased but were also highly variable, with peaks corresponding to rain events (Minear and Tschantz 1976). A major problem in sediment transport has been improper sediment retention pond construction and maintenance (Kash et al. 1977). Still, in the New River Basin, modified mining procedures, enforcement of specific revegetation measures, and installation of silt-control structures were inadequate to remedy the sedimentation problem (Minear and Tschantz 1976).

Typically, sedimentation is at its maximum level during the period of mining, decreasing within 1 to $2 \mathrm{yr}$ after cessation of mining (U.S. 
Army Corps of Engineers 1974). In the New River Basin, however, sedimentation was found to increase even after mining had ceased; the size of particles entering streams increased with time, the largest, slowest-moving particles being found last in a downstream stilling basin (Minear and Tschantz 1976). Stream bottoms may remain sedimented even after refuse piles have been reclaimed (Martin 1976).

Sedimentation from coal mining and mine-site processing is most serious where steep terrain is prevalent and where precipitation is abundant and intense (U.S. Army Corps of Engineers 1974, Kash et al. 1977). Mountainous areas with little space for adequate retention ponds pose a major problem (Dvorak et al. 1977). In areas of level and rolling topography, area stripping and open-pit mining present lesser sedimentation hazards, but problems nevertheless result from stream-edge mining (U.S. Army Corps of Engineers 1974).

Southern Appalachia is considered the area of most severe actual and potential sedimentation problems, with steep slopes and abundant and intense precipitation (U.S. Army Corps of Engineers 1974, Kash et a1. 1977). Summer rainstorms in the Appalachian area cause intense, rapid runoff with erosion (U.S. Army Corps of Engineers 1974). In eastern Kentucky, thousand-fold increases in sediment yields have been measured for contour strip areas compared with und isturbed forests (U.S. Army Corps of Engineers 1974). Indicative of the diffuse nature of the sedimentation problem, access and haul roads in that area account for $10 \%$ of the total 1 and disturbed by contour and auger mining (U.S. Army Corps of Engineers 1974). Runoff from slurry pond overf low and refuse pile erosion after storms are a particular problem in the mountainous regions of southern West Virginia and eastern Kentucky (Martin 1974b). Abandoned strip mines are the primary source of sediment in the Tombigbee-Black Warrior Basin (South Atlantic-Gulf Water Resnurce Region) (U.S. Army Corps of Engineers 1974).

In the middle basin of the Ohio Water Resource Region, contour and auger mines, roads, and processing plants contribute sediment to the Kanawha, Guyandotte, and Big Sandy River Subbasins, and contour and area stripping are important sources in the Muskingum Subbasin. In the 
lower basin of the Ohio Water Resource Region, sediment from coal mining is a problem in the upper Kentucky and Cumberland, Green, Tradewater, Sabine, and Wabash River Subbasins (U.S. Army Corps of Engineers 1974). While not considered as severe a regional problem in the Tennessee Water Resource Region (U.S. Army Corps of Engineers 1974), sedimentation from coal washing has caused major problems in the Guest River and the Dump's Creek, which are tributary to the Clinch River (Cairns et al. 1971).

In the Mid-Atlantic Water Resource Region, sedimentation is most severe as a result of surface mining of anthracite (U.S. Army Corps of Engineers 1974). Sedimentation can also be significant in the midwest because of abundant rainfall and the density of mining in some areas (Kash et al. 1977). Sedimentation in the Upper Mississippi Water. Resource Region is a problem in the Big Muddy and Kaskaskia River Basins in Illinois and the Des Moines River Basin in Iowa, a result of area stripping (U.S. Army Corps of Engineers 1974). Similarly, high suspended solids levels have been identified as a problem in some western coal fields (Habegger et al. 1977). Increased sediment loads in the northern Great Plains and Rocky Mountains result from short, high-intensity, local precipitation events (Kash et al. 1977).

In accordance with the Surface Mining Control and Reclamation Act of 1977, sediment discharges from surface and underground mining are to be controlled (Office of Surface Mining Reclamation and Enforcement 1979). For most states, total suspended solids (TSS) levels in discharges are not to exceed $70.0 \mathrm{mg} / 1 \mathrm{iter}$ at any time, or $35.0 \mathrm{mg} / \mathrm{liter}$ as an average for 30 consecutive discharge days. The corresponding values for Arizona, Colorado, Montana, New Mexico, North Dakota, South Dakota, Utah, and Wyoming are 45 and $30 \mathrm{mg} / 1$ iter, respectively. With respect to the southeastern United States, where the sedimentation potential is most severe, one analys is indicates that these regulations should keep TSS levels in mined areas with in the expected range for nonmined areas (Davis et al. 1978). Even the large-storm exemptions of the regulations would result in TSS levels comparable to levels in basins with other land uses. 
As in the case with hydrologic effects, the extent to which the regulations promulgated pursuant to the Surface Mining Control and Reclamation Act of 1977 are applied and enforced will determine the extent to which effects on water quality $(\mathrm{pH}$, sediment, trace substances) are controlled.

\subsection{WATER QUALITY EFFECTS ON BIOTA}

The major water quality effects on biota from mining and mine-site processing are from (1) sedimentation, (2) acid drainage, (3) alkaline drainage, and (4) nutrient enrichment.

Sedimentation occurs as a result of erosion and from spillage from coal washing areas. Erosion is particularly acute in the mountainous coal mining regions of the eastern United States, but it is also a considerable problem in western mining areas where highly erodible soils exist, vegetation is generally sparse, and rainfall events, though sporadic, are intense (Dvorak et al. 1977). In addition to the scouring impacts discussed previously (Section 1.2), sedimentation has several other effects on the biota of a stream. The turbidity it produces decreases photosynthesis, which can result in the elimination of benthic plants and the virtual elimination of phytoplankton (Fogg 1975). Such a decrease in the autotrophic communities usually has concomitant ramifications for higher trophic levels, including decreased standing crops and species composition changes (Russe11-Hunter 1970). Sedimentation tends to smother benthic animals as well and creates an unstable substrate on which few organisms can recolonize (Hart and Fuller 1974). The loss of a significant portion of the benthic fauna usually has a detrimental influence on invertebrate predators; this effect alone has been cited as eliminating various fish species from affected streams (Hynes 1971). Direct effects of sedimentation on fish include clogging of gills, loss of spawning habitat, reduced resistance to disease, and disruption of migrations (Dvorak et al. 1977). The sediment may also carry high levels of organic compounds that can cause local deoxygenation upon decompusition, thereby stressing organisms directly or producing indirect effects through an influence on the toxicity of other compounds. 
Acid drainage contains high levels of TDS (much of which is contributed by sulfates), has a low pH, sometimes has high hardness, and contains numerous trace contaminants, including heavy metals. Because of the complexity of this type of effluent, biotic effects are variable and are often highly site-specific (Roback and Richardson 1969). Thus, for example, acid drainage that enters a highly calcareous stream may be rapidly neutralized and rendered relatively innocuous with in a short distance downstream. Conversely, the same effluent added to a water body that has little buffering capacity may exert effects for a considerable distance.

The lowering of the $\mathrm{pH}$ of a water body can have a complex effect on communities, and the responses of different organisms are highly variable (Tomkiewicz and Dunson 1977). Some species thrive in very low $\mathrm{pH}$ environments, including sulfur and iron bacteria (e.g., Thiobacillus and Ferrobacillus), which help oxidize the sulfide minerals associated with some coals to produce the acidity in the effluent (Dugan 1972). However, some organisms do not tolerate $\mathrm{pH}$ values much below neutral. For example, most blue-green algae display optimum growth between $\mathrm{pH}$ 7.5 and 9.0 and will not survive for long periods below pH 6.0 (Fogg et al. 1973). Most fish are able to live within a fairly wide $\mathrm{pH}$ range (e.g., pH 5 to 10); sensitivity to bacterial diseases increases greatly be low about $\mathrm{pH} 5$ and is a major factor preventing long-term survival at lower pH values (Bennett 1970). The mechan isms that govern $\mathrm{pH}$ tolerance are poorly known for most organisms because of the multiplicity of effects, both direct and indirect, which the hydrogen ion concentration can have on biota. A significant indirect effect of $\mathrm{pH}$ is its influence on the ionization of compounds and the solubility of certain ions. Most heavy metals are more soluble at lower pH values; therefore, heavy metal effects are usually more pronounced at these leve is (Van Hook 1978).

The physiological bases for the effects of altered TDS levels caused by the addition of acid drainage are usually related to osmotic influences rather than toxic reactions (King et al. 1974). The sulfate ion, for example, is not highly toxic to most organisms, even at high concentrations, but many species cannot survive in ionic strengths as 
high as those associated with acid drainage. However, there is some evidence that the effects of altered hardness are more complex than this for at least some species. For example, calcium and other divalent cations (ions with a double positive charge) may alter the efficiency of ion uptake systems in some plants (either negatively or positively) (Fogg 1975). Of particular pertinence is the fact that hardness can greatly modify the toxic effect of a given concentration of heavy metals. In general, heavy metals exert greater toxicities in soft water than in hard water (National Academy of Sciences and National Academy of Engineering 1973).

Metals commonly found in coal mining and processing effluents are listed in Table 1, along with typical concentrations encountered. Levels of certain metals can reach such high values that changes in $\mathrm{pH}$ (to more alkaline) or Eh (to less reducing) can precipitate blanket-like deposits of the metal hydroxides in the bottom of the water body (Dvorak et al. 1977). Iron and aluminum hydroxides, in particular, are commonly found in streams located a short distance from waste outfalls as a result of partial neutralization of the acidity in the effluent by the receiving stream or its substrate. Although these compounds are not highly toxic in the precipitated form, they produce effects that are quite similar to the effects of other extraneous sediments (see previous discussion) (Hynes 1971).

Because of the number of toxic trace metal contaminants commonly contained in acid minc drainage, a variety of toxic effects may he produced. Aside from the toxicities produced by each ion individually, several synergistic effects (i.e., total effects that are greater than the additive effects of the individual ions) and antagonistic effects can be produced by the coexisting metals (Lind and Campbell 1970, Van Hook 1978). The toxicities of trace elements from coal to aquatic organisms are listed in Dvorak et al. (1977) and Cushman et al. (1977).

As indicated in Section 1.3, mine and processing waste effluents commoniy contain concentrations of elements in excess of criteria designated for the protection of aquatic life. The extent to which any given effluent will exert effects on a receiving stream will depend not only on the concentration of the toxic constituents in the effluent but 
on the dilution capacity of the stream. The ecological effects from toxic metal additions are similar to those produced by many toxicants; that is, the communities become more simplified (have less diversity because only resistant organisms survive), and overall production drops (Roback and Richardson 1969, Lind and Campbe 11 1970, Hynes 1971).

In addition to direct toxic effects, many of the trace metals are bioaccumulated. Thus, even low environmental concentrations may indirectly result in toxic effects at higher trophic levels, while organ isms lower on the food chain are unaffected (Van Hook 1978).

Several studies have been conducted on the ecological effects of adding acid mine drainage to streams and lakes (e.g., King et al. 1974, Smith and Frey 1971). Although spec ific details vary from site to site, certain common conclusions have emerged. In general, diversity of the major communities decreases in proportion to the amount of pollutants added. Those organisms that do survive can obtain large standing crops, however, because much of the competition which they formerly experienced is removed. Sport fish, particularly the salmonids, are among the first organisms to disappear. In some cases, this results from direct toxic effects, but in others it. is r.alsed hy an influence on their food supply (e.g., the benthic invertebrates). rotal biomass of autotroph3, primary consumers, and secondary cursumers may either increase or decrease (Smith and Frey 1971; Hynes 1971, 1972; Sculthorpe 1967).

Alkaline drainage occurs primarily in the western United States, where pyritic minerals are generally scarce in the coal and where the overburden contains large quantities of sodium, calcium, magnesium, carbonate, bicarbonate, sulfate, and chloride. Thus, it is the leachate from the overburden that produces adverse effect.s rather than runoff from the coal and associated minerals. In general, the constituents of alkaline drainage (sodium, calcium, magnesium, carbonate, bicarbonate, sulfate, and chloride) are not highly toxic, but they frequently occur at high enough concentrations in the receiving waters to induce osmotic effects and ionic imbalances (Dvorak et al. 1977). The effects are highly site-specific, however, because the relative quantities of the ions in the effluent depend on the 
nature of the overburden being leached. The sporadic precipitation in much of the western United States makes many of the alkaline drainage inputs episodic rather than continual. In extremely arid areas, leachates from the overburden may only reach ephemeral streams, which have no true aquatic biota; impacts to these would, thus, be minimal (Dvorak et a1. 1977).

If alkaline drainage inputs to a particular water body are not excessive, no changes in community structures or population densities may be noted. However, large additions of the previously listed ions may result in a flora and fauna that are more euryhaline (Hynes 1972, Lind and Campbell 1970). Such biotic assemblages can be very diverse and productive, although extreme salinities or hardness generally create low diversity (but potentially high population densities of the individual components) (Hynes 1971). Additions of carbonate and/or bicarbonate to highly eutrophic systems can stimulate production if the major autotrophs are carbon-limited (Hutchinson 1967). These ions also tend to reduce $\mathrm{pH}$ fluctuations by buffering the water. In general, the addition of even large amounts of bicarbonate/carbonate produces little damage to ecosystems (National Academy of Sciences, National Academy of Engineering 1973).

Small quantities of substances other than water are occasionally used in washing coal. Although some alcohol and kerosene may escape into the environment, for example, the quantities are expected to be so small that only very loralizer efferts will be felt. Dilute quantities of alcohol can actually stimulate the growth of certain heterotrophs because it can be used by them as an energy source (Brock 1966).

\subsection{WATER USE}

Effects of coal mining and mine-site processing on water use fall into two major categories: effect.s on water availability (mining withdrawals and consumption, reduced stream flow, dewatered aquifers, etc.) and effects on water quality sufficient to constrain use (excessive acidity, trace substance contamination, suspended sediment, hardness, etc.). The effects of coal mining on use of water resources are discussed in the National Strip Mine Study (U.S. Army Corps of Engineers 1974). 
Various estimates exist for the water needs of coal mining, processing, and reclamation. It has been estimated that mining requires 15 to $57 \mathrm{~cm}^{3} / \mathrm{kg}$, that coal mining waste disposal requires an additional $30 \mathrm{~cm}^{3} / \mathrm{kg}$, and that reclamation irrigation in the semiarid West requires another $61 \mathrm{~cm}^{3} / \mathrm{kg}$ (Kilpatrick and Davis 1976). Trelease and Burman (1975) estimated water demand for reclamation irrigation in the Powder River Basin in eastern Wyoming, where about 9 hectares (ha) of land are affected per million metric tons of surface-mined coal. They calculated the demand to be about $3 \times$ $10^{3} \mathrm{~m}^{3} / \mathrm{ha}$ of reclaimed land, assuming irrigation for one year. This is equivalent to about $25 \mathrm{~cm}^{3} / \mathrm{kg}$ of coal. The $46 \times 10^{6}$ $\mathrm{m}^{3} /$ year total demand by mining (including irrigation) in the mid-1970s (Kilpatrick and Davis 1976) could increase significantly if more reclamation irrigation is required. If water development projects are necessitated by the increased water demand for irrigation, the replacement of flowing waters by static ones would also potentially affect some uses (such as aquatic habitat and recreation). Complicating the estimation of the impact of coal mining water demand is the fact that in the western United States the coal beds themselves may be important ground-water aquifers (Dvorak et al. 1977).

The importance of the loss of surface waters, dewatering of aquifers, lowering of hydraulic heads, disappearance of springs, etc., will depend on the uses made of them (for water supplies, wildlife habitat, etc.). In northern Appalachia, mining has disturbed important limestone aquifers, and in southern Appalachia, perched aquifers have been dewatered; in both areas, wells have been damaged by blasting (Kash et al. 1977). The loss of shallow ground-water supplies as a result of deep mine subsidence (primarily in Federal Regions III, IV, and $\mathrm{V}$ ) also affects their beneficial use ( $\mathrm{Hill}$ and Bates 1977). Texas lignite deposits are associated with important ground-water aquifers (Kash et al. 1977). In the western United States, coal-bed ground water, even if not of drinking-water quality, is used for livestock watering (Dvorak et al. 1977). In the northern Great Plains, ground water is used heavily for domestic and livestock water supplies (Kash et al. 1977). However, subirrigation of alluvial valley floors is 
vital to agriculture in some western states (Kash et al. 1977, Carter et al. 1977), and the disturbance of their ground-water systems is of particular concern (Carter et al. 1977). Although springs are important to livestock and wildlife, these populations may benefit if some ground-water aquifers are exposed (Kash et al. 1977). Ground-water quality can at least be reduced locally by influent leachates. In the western coal fields, for instance, leached salts can degrade already marginal supplies by increasing the TDS concentrations, trace metals, and hardness. Increased levels of elements such as iron and manganese can render aquifers unfit for use. Lowered pH values can cause aquifer and well-clogging by providing an environment favorable to the growth of iron-fixing bacteria.

Factors such as elevated levels of suspended sediment, dissolved solids, acidity, trace substances, etc., may constrain water uses that are dependent on water quality. These uses include habitat for biota; drinking water, livestock watering, irrigation, public water supplies, industrial uses, pollutant dilution and assimilation, recreation and aesthetics, and navigation. Increased water treatment costs may be incurred to meet quality criteria.

Water uses for aquatic life habitat and for recreation have been considered the most constrained by coal mining (U.S. Army Corps of Engineers 1974). Effects on fishing and other aspects of aquatic ecology are considered more fully in Section 1.4. In addition to effects on fishing, impacts on recreational water use have been (1) of an aesthetic nature (views of mines, waste piles, and haul; water coloration from iron), (2) related to accelerated corrosion of piers and other instream structures as a result of acid drainage, and (3) related to navigability and anchorage limitations because of sedimentation (U.S. Army Corps of Engineers 1974). Commerc1al navigation has been affected by acidity in the upper Ohio basin (Monongahela River), where boats, barges, dams, and locks have been corroded, and by sedimentation, with dredging necessitated in the Schuylkill (Mid-Atlantic Water Resource Region) and Big Sandy (Ohio Water Resource Region) Rivers (U.S. Army Corps of Engineers 1974). 
Acidity affects the self-purification and sewage-assimilation capacity of streams, with major implications for downstream domestic withdrawals (U.S. Army Corps of Engineers 1974). Water supplies are imperiled, particularly in areas such as southeastern Ohio, Pennsylvania, and northeastern West Virginia (Ohio Water Resource Region), where alternative supplies are not available. Significant costs may be incurred due to corrosion as well as for water neutralization and softening. Where small streams are used, sediments and turbidity, especially, clog intake pipes and increase treatment costs - a major problem in southern West Virginia, eastern Kentucky, Tennessee, and western Virginia (Ohio and Tennessee Water" Resource Regions) (U.S. Army Corps of Engineers 1974). Where alkaline drainage is a hazard, water uses may also be affected by changes in quality: increased total dissolved solids are considered a problem in Colorado, where wells and springs are used by livestock and wildife (Kash et al. 1977 ).

In accordance with the Surface Mining Control and Reclamation Act of 1977, effects on water use resulting from effects on water availability and quality are lo be controlled. Additinnally, where a legitimate use of ground water or surface water is affected by contamination, diminution, or interruption because of the miring operation, the affected supply is to be replaced by the mining permittee (Office of Surface Mining Reclamation and Enforcement 1979). The extent to which regulations in accordance with the act are applied and enforced will determine the extent to which water uses are protected from the adverse potential effects of coal mining. 


\section{TRANSPORTATION}

\subsection{WATER QUALITY}

Many of the effects of coal transportation on water quality are common to all the transportation modes - railroads, barges and ships, slurry pipelines, conveyor belts, and trucks. The environmental effects of the various modes have been discussed (Dvorak et al. 1977). Erosion and resulting siltation, turbidity, and sedimentation are expected to be associated with railroads. This is especially true in the Appalachian region, where precipitation is high, and in the northeastern mountains, where railroads are proximal to streams, and valleys are narrow. Lesser problems are expected in the West (because of aridity and because railroad lines can be planned to avoid paralleling streams), although sedimentation at stream crossings will still be a problem. Sedimentation problems are also experienced with barges (the effects of dredging to maintain channels; construction; bank erosion if barge traffic is heavy in a narrow channel) and with slurry pipelines (construction impacts are likely, although the aridity in the western states and generally flat terrain in the midwestern states would limit these impacts). Sedimentation is also a hazard with trucks (the effects of road construction and maintenance, with erosion and sedimentation being especially troublesome in mountainous terrain such as Appalachia) (Dvorak et al. 1977). Similarly, sedimentation is a hazard with conveyor bclts, which are particularly useful in rough terrain.

Spills, leaching, and leakages of coal and/or fuels are also seen as a problem common to all transportation modes. The derailment of a unit coal train could result in the spilling of about 9,000 metric tons of coal; seepage from loading and unloading stockpiles is also seen as a problem (Dvorak et al. 1977). Slurry spills are a potential problem with pipelines, while spills of coal and fuels are possible from barges and trucks (Dvorak et al. 1977). Spills from barges and ships (with loads of up to 57,000 metric tons) would, of course, be most likely to affect surface water quality directly berause of proximity, whereas 
effects from the other modes would be more dependent on exact location, topography, soil mobility, etc. Although the geographic distribution of water quality effects would depend on transportation routes to the points of use, the effects would be similar in nature to those from mining, storage, and mine-site and onsite processing (Sections 1 and 3 ), that is, sedimentation and turbidity, trace substances, etc.

The infiltration of fluids (including leachate) from coal and/or liquid fuel spills is a potential problem where ground-water quality is concerned. Depending on the type and amount of liquid spilled or leachate generated, as well as the nature of the soil and bedrock present in an area, aquifer contamination may or may not occur. The ground-water quality effects are, therefore, site specific, although. generalizations can be made. In areas typified by a thick, clay-rich soil, the infiltration of contaminants should be minimal. Besides adsorption onto individual clay particles, the permeability for transmission of fluids would be low. Where overburden is thin, consisting of particles larger than $125 \mathrm{~m}$ (fine sand), or where jointed bedrock is exposed, percolation of contaminants would occur rapidly. Areas underlain by carbonate bedrock would be especially prone to aquifer degradation from spills, because of rapid ground-water movement in the solution openings and joints prevalent in these rocks.

The problems of dewatering disposal at the utilization end of the slurry pipeline and en-route spills or leaks are more complex. Dewatering disposal will be interrelated with the degree to which the wastewater can be used productively; for utilities, this wastewater serves as part of the cooling water requirement ( $K i$ lpatrick and Davis 1976). There is uncertainty as to whether the pipeline water will pick up dissolved solids and acidity under the prevailing anaerobic conditions (Davis and Boegly 1978) (see Section 1 for a discussion of acid formation from mining).

Effects on water quality from spills, leakages, and leachates may be expected to increase roughly proportionately with the increased demand and use of coal. On the other hand, increases in construction-related effects will be determined by the extent to which 
additional lines, roads, slurry pipelines, etc., are required; this extent is undetermined presently. The impoundment of streams and the construction of locks required for barge traffic alter aquatic habitats and interfere with fish migration (Dvorak et al. 1977, Minckley and Deacon 1968).

\subsection{AQUATIC BIOTA}

Transportation effects on aquatic biota are difficult to evaluate because the proportional quantity of coal to be hauled by each mode is unknown, the new transportation routes are unknown, and the accident rates and specific operational characteristics for the newer conveying methods (such as the slurry pipeline) are not known. In general, construction for the terrestrial transport methods will increase sedimentation problems, particularly in the mountainous East and the arid West (Dvorak et al. 1977). Coal spills and slurry spills near or in a water body will provide the potential for several of the types of effects discussed in Section 1, primarily, acid or alkaline drainage and sedimentation effects. The overall severity of such impacts is expected to be considerably less than those produced by mining and mine-site processing. However, the potential does exist for severe local effects (e.g., in the case of a large spill near a small, pristine, poorly buffered lake).

\subsection{WATER USE}

Although presumably smaller in magnitude, water use effects as a result of sedimentation and water quality deterioration will be similar qualitatively to corresponding effects of mining and mine-site processing (Section 1.5), and storage and onsite processing (Section 3.3).

A major problem, unique to the slurry pipeline, is the consumptive water requirement for the slurry. The point of water demand would frequently be in regions already short of water, and difficult legal and institutional problems must be overcome if this technology is to be implemented (Kilpatrick and Davis 1976). Typical water requirements 
are expected to be about 1 cubic meter of water per metric ton of coal (30 $\mathrm{ft}^{3} /$ ton) (Kilpatrick and Davis 1976). Although

it cannot be stated how the water will be provided, conflicts over water rights may be anticipated. If regional consumption is increased, some drawdown of ground-water aquifers and lake levels may result (Dvorak et al. 1977).

Ground water would be diverted from some areas because of local depression of the potentiometric surface by increased pumpage. In water-short areas, ground-water mining could occur (discharge is greater than recharge to the system). Areas in which ground water is already being mined (such as the High Plains of Texas) would be most affected by an increased demand for slurry water. If water development projects are necessitated by the slurry pipeline water demand, or by barge or ship transportation, replacement of flowing waters by static ones would also potentially affect some uses (aquatic habitat, recreation, etc.). 


\section{STORAGE AND ONSITE PROCESSING}

\subsection{WATER QUALITY}

The effects of coal storage are similar to those of mine-site processing and refuse (gob and slurry) disposal, although of lesser magnitude (Dvorak et al. 1977). Contact with water is controlled by storage practices, and the coal piles generally contain lower levels of contaminants than do processing wastes (Dvorak et al. 1977). Contamination of surface and ground water may result, however, from runoff and infiltration from coal pile leachates; parameters of concern include coal fines, humic acids, low pH, acidity, sulfate, iron, and other trace elements. Additionally, coal storage piles may be sprayed (for dust suppression) with alkyls, phenol, ether, and ethylene (Dvorak et al. 1977), which may be toxic to aquatic biota and may contaminate ground-water reservoirs.

Water quality measurements for a variety of coal leachates and coal pile drainages are given in Table 3. Characteristically, these effluents and potential effluents exceed many of the standards and criteria for drinking water, livestock water, irrigation water, and protection of aquatic biota (Table 2). Consequently, dilution by receiving waters would be required so that the final concentrations in the environment would not be in violation of these criteria. Onsite coal storage is regulated for steam electric power plants (40 CFR Part 423); runoff as a point-source must have a $\mathrm{pH}$ of 6.0 to 9.0 and a TSS level of no greater than $50 \mathrm{mg} / 7$ iter (U.S. Environmental Protection Agency 1974). Specific effluent limitations for coal storage at other coal-use facilities have not yet been promulgated.

\subsection{AQUATIC BIOTA}

Effects from storage and onsite processing result mainly from coal runoff. The constituents in the effluent are virtually the same as those emanating from coal mining and mine-site processing (Section 1), but the absolute amounts are generally much less. The contaminant quantities are usually lower because: (1) the coal has usually been previously washed and (2) water contact is kept to a minimum in coal 
Table 3. Representative water quality measurements for coal pile leachate and coal pile drainage (all values except $\mathrm{pH}$ expressed as $\mathrm{mg} / \mathrm{liter}[\mathrm{ppm}]$ )

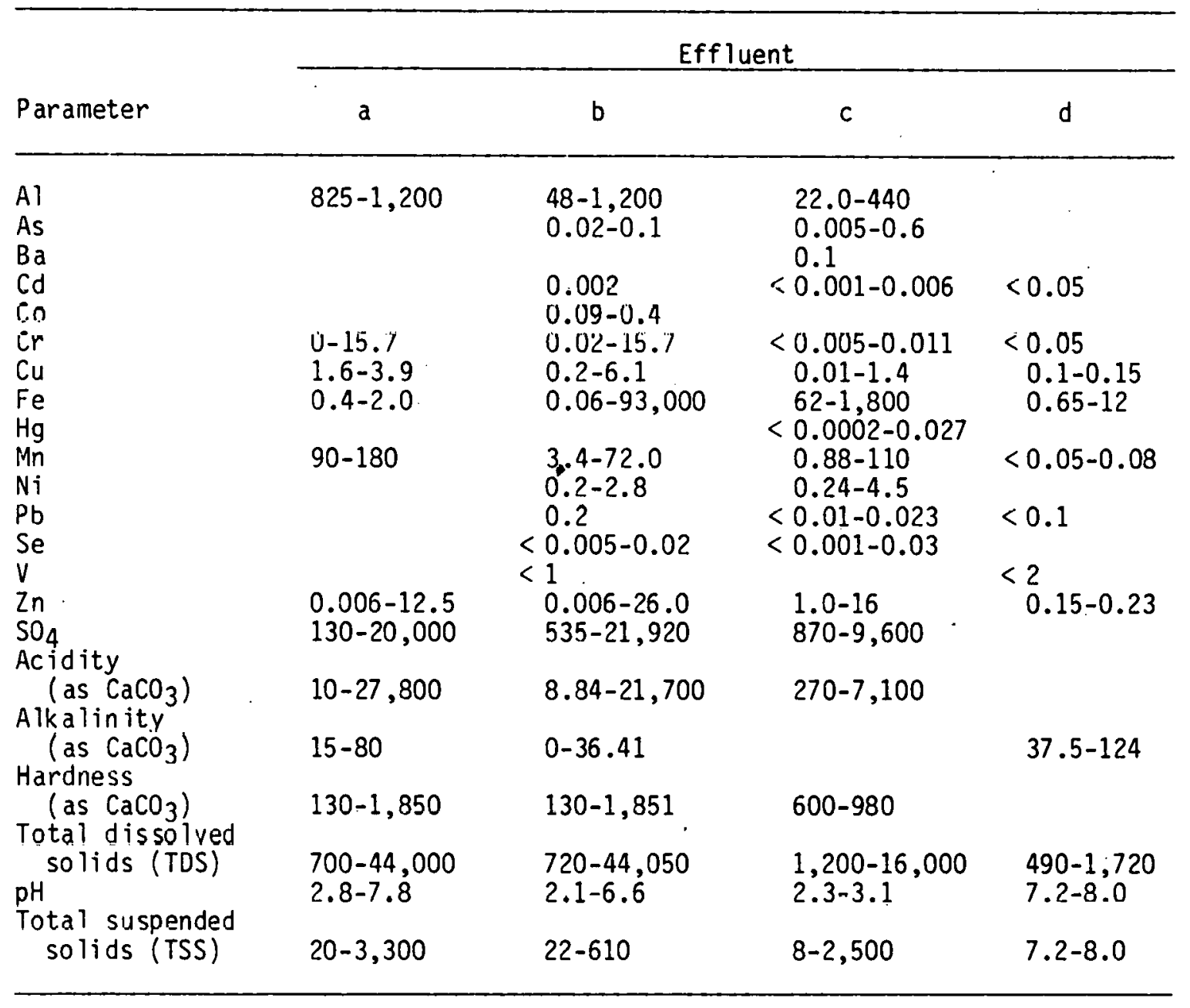

aCoal pile drainage, unspec ified coal. From Federal Energy Administration (1977), Table IV-9.

bCoal pile drainage, unspecified coal. From Davis and Boegly (1978), Tables $4,5,12,13$, and 14 .

CTVA plant coal pile drainage, unspecified coal. From Davis and Boegly (1978), Tables 9, 10, and 11 .


and anaerobic (pH 8.0) conditions. From Davis and Boegly (1978), Table 6. 
storage piles because wet coal has a lower heat value per un it of weight. For a discussion of the effects of the constituents on aquatic biota, see Section 1.4.

Coal storage piles are occasionally sprayed by miscellaneous chemicals for dust control. Most of these are toxic organics (e.g., phenol, ether, or ethylene glycol), but the amounts used are small enough that little of the material is added to surface waters. Toxic effects to aquatic biota of these compounds in situ have not been distinguished from the effects of the other contaminants (Dvorak et al. 1977).

\subsection{WATER USE}

The primary potential water use effect of storage and onsite processing is constraint on water use as a result of contamination of surface and ground waters. Characteristically, coal pile drainage exceeds promulgated criteria and standards for water-quality-dependent uses (Table 2). Although of lesser magnitude, the coal pile runoff and infiltration problems are seen as a similar to the water quality and use effects from mine-site processing discussed in Section 1 (Dvorak et a). 1977). Some consumptive water use is required for occasional water sprays of coal storage piles for dust suppression (Dvorak et al. 1977). 


\section{COMBUSTION}

Effects on water resources as a result of the combustion of coal will be limited in this discussion to those stack emissions specific to coal. Effects not specific to coal combustion (thermal discharges, water consumption for cooling, and entrainment and impingement of aquatic biota) will not be addressed.

\subsection{WATER QUALITY}

Effects on water quality from the combustion of coal fall into two major categories: the effects of acid rain and the effects of trace substances in stack emissions. Dvorak et al. (1977) contains a discussion of these effects on water quality.

The acid rain problem has been identified by the Committee on Health and Environmental Effects of Increased Coal Utilization as the most serious environmental effect associated with increased coal utilization (U.S. DHEW 1978). Since the mid-1960's, the region of acid precipitation has been spreading southwestward and westward, so that by 1973 most of the area east of the Mississippi River was affected (Glass 1977). Acid rain is most severe in the industrialized Northeast (Pennsylvania, New York, and New England) and is affected not only by emissions within that region but also by emissions from the Midwest (Dvorak et al. 1977). The precipitation pH of some storm events in the Northeast is in the 2.1 to 3.6 range, but more generally for the northeastern United States, it is in the 4.0 to 4.2 range (Glass 1977). For comparison, the $\mathrm{pH}$ of precipitation as a result of equilibrium with atmospheric $\mathrm{CO}_{2}$ is 5.6 (Galloway et al. 1976). Precipitation at Ithaca, New York, in the Adirondack Mountains, New York, and in the White Mountains, New Hampshire, has had a measured pH of 3.5 to 4.5 ; at Ithaca, sulfuric acid contributed $71 \%$ of the free acidity at a pH of 3.84 and $49 \%$ of the total acidity in titration to a $\mathrm{pH}$ of 9.0 , while nitric acid contributed $28 \%$ of the free acidity and $19 \%$ of the total acidity (Galloway et al. 1976). 
The most direct effects of acid rain on surface water quality include lowered pH and reduced buffering capacity (Dvorak et a1. 1977, Glass 1977). Lake acidification is most serious in the Adirondack Moutains (where the igneous and metamorphic bedrock geology results in low TDS and low buffering capacity, with dominance by calcium, magnesium, sulfate, and chlorine ions) and in New England [particularly the White Mountains of northern New Hampshire and western Maine (granitic bedrock geology)] (Dvorak et al. 1977). Typical pH levels of Adirondack lakes range from 4.5 to 5.5 , with $51 \%$ of 217 investigated lakes at altitudes above $600 \mathrm{~m}$ having a pH below 5.0. (Dvorak et al. 1977, Glass 1977). Similar effects have been noted in the La Cloche Mountains of southeastern Ontario (many with pH below 4.5) (Dvorak et al. 1977) and in Scandinavia. Other potential problem areas are the pre-Cambrian igneous regions in the Piedmont and Appalachia of North Carolina and Virginia, as well as dilute headwater streams and alpine lakes of the Cascade Mountains of Oregon and Washington (Dvorak et al. 1977 ).

Infiltration of acid rain would affect the $\mathrm{pH}$ of a ground-water reservoir only very gradually, if at all. Because many aquifers are comprised of carbonate rock such as limestone or dolomite, or calcareous formations of some type, acidic recharge would be quickiy neutralized. Only in areas where the aquifers are comprised of intensely fractured crystalline rock would the acid rain problem be maximized. Recharge and discharge are more rapid in fractured rocks of granitic and gneissic composition, and any buffering action would be minimal because of their "acidic" composition. Aquifer degradation by acid rain recharge would probably not be appreciably detectable for hundreds of years.

Indirect effects of acid rain on water quality include increased trace element solubilization and availability because lowered pH strips trace elements from bonding sites on organic and inorganic complexing agents (Dvorak et al. 1977). Acidified lakes frequently have elevated concentrations of a luminum, manganese, zinc, cadmium, lead, copper, and nickel, both from increased deposition and from resolubilization from 
sediments (Glass 1977). There are toxicity and food chain implications from elevated levels of trace elements, but low concentrations of essential trace elements may be the limiting factor controlling lake productivity in some areas, particularly in some oligotrophic lakes (Goldman 1972). Thus, there are implications for eutrophication, if concentrations of these elements are increased. Accelerated leaching of major nutrient ions from soils, where they limit productivity, may also have implications for eutrophication (Glass 1977). The buffering capacity of lakes is degraded by acid rain inputs, so that new inputs may cause $\mathrm{pH}$ to drop sharply (Glass 1977).

In addition to mobilization from terrestrial and sediment sources, and increased availability due to acid rain, trace element inputs from effluent emissions and deposition may potentially affect water quality. Several trace elements have been identified to be of concern in aquatic environments: arsenic, cadmium, cobalt, mercury, copper, lead, selenium, manganese, chromium, and tin (Dvorak et al. 1977, Van Hook 1978). In a conservative study of trace element deposition in a hypothetical closed lake, with 30 years of operation from a 1000-MWe power plant, only mercury and zinc would exceed criteria for the protection of aquatic biota (Dvorak et al. 1977). Van Hook (1978) concludes that trace element enrichment from coal combustion atmospheric effluents is not a significant hazard in surface aquatic systems, although he warns that the data are incomplete. Klein et al. (1975) estimate that coal combustion adds significantly to the natural fluxes of $\mathrm{Br}, \mathrm{Hg}$, and $\mathrm{Se}$ as a result of atmospheric discharges. The amounts of trace metals leaching into a ground-water reservoir from combustion would not be significant. $\mathrm{Cl}$ ay minerals in the overburden and bedrock would probably adsorb nearly all trace metals (ion substitution would also take place).

\subsection{AQUATIC BIOTA}

The biotic consequences of lowered $\mathrm{pH}$ in surface waters due to acid precipitation influx are highly site-specific and depend on (1) the degree to which the $\mathrm{pH}$ is lowered, (2) the existence, if any, 
of other stresses on the system, (3) the biotic assemblages already present in the affected area, (4) the persistence of the acid precipitation (seasonality, frequency) and the potential for the communities to recover between $\mathrm{pH}$ "insults," and (5) the regional geochemistry. In general, the greatest damage to community composition, population sizes, and other ecological parameters occurs when the $\mathrm{pH}$ shifts from neutral or alkaline to a permanent acid condition. (Hynes 1971). Shifts of this nature are generally accompanied by sharp drops in productivity, the magnitude of which is proportional to the magnitude of the shift. Although certain communities may actually experience increases in diversity with a lowered pH (e.g., the phytoplankton) (Brock 1966), most experience reductions in the number of taxa (Beamish and Harvey 1972, Moss 1973). Fish are particularly sensitive to $\mathrm{pH}$ shifts below about 5.5, and man-induced values below this have been associated with sharp drops in fish production or virtual fish extinction (e.g., in the Adirondacks) (Cogbill and Likens 1974). Other effects of lower pH on aquatic biota are discussed in Sections 1.4, 2.2, and 3.2.

If the $\mathrm{pH}$ shifts occur relatively infrequently, there may be few discernible effects on ecological parameters because short-term exposure either may not affect the organisms or the damage may be compensated for by recruitment or reproduction (Hynes 1971).

Recent evidence (Cronan and Schofield 1979) suggests that the addition of aluminum by acid leaching in noncalcareous watersheds may be a major factor in stressing aquatic systems. Their work suggests, for example, that much of the fish mortality experienced in the Northern Appalachian chain may be due more to a response to aluminum concentrations than to $\mathrm{pH}$ levels, per se.

Hard alkaline waters are rarely affected by acid rain because their buffering capacity usually exceeds the ability of any inputs to modify the pH. Because these waters obtain their hardness and alkalinity from surrounding geological features such as carbonate or calcareous bedrock, which are generally abundant, any small decreases in buffering capacity that do occur are compensated for by additional geological inputs (Dvorak et al. 1977, Hutchinson 1967). 
Although the addition of trace metals to aquatic environments from the deposition of airborne combustion effluents represents a potential problem, it is not generally considered to be of major concern (Dvorak et al. 1977, Van Hook 1978). The quantities deposited are usually several orders of magnitude less than the amounts added from other sources. However, any incremental additions in areas already near problem levels can result in detrimental effects (Klein and Russell 1973). Moreover, for a few elements, such as $\mathrm{Hg}$, the contribution may be significant, relative to other sources (Sectiun 4.1). A few studies (e.g., Henriksen and Wright 1978) attribute significant increases in heavy metals to deposition phenomena and/or increased mobilization of such substances by greater hydrogen ion concentrations.

\subsection{WATER USE}

Any effects on water use from coal combustion effluents would be expected to occur from deterioration of water quality, most probably from acidification and increased trace element levels. Although similar qualitatively to corresponding effects from other parts of the coal fuel cycle, these effects, being related lo atmospheric deposition, would be more diffuse and hence less identifiable as resulting from particular sources. Effects not specific to coal combustion (such as thermal effects, impingement, and enlraiment) are outside the scope of this paper. 


\section{WASTE COLLECTION AND DISPOSAL}

\subsection{WATER QUALITY}

Potential effects on water quality from waste collection and disposal are related to increases in trace contaminants, $\mathrm{pH}$, chemical oxygen demand, and dissolved and suspended solids. A more thorough discussion of the environmental effects of waste disposal from coal utilization is contained in Environmental Protection Agency (1977a) while Van Hook (1978) discusses the state of the art with respect to mobilization of trace elements from coal combustion wastes.

Ash pond overflow, dike failure, ash-slurry pipeline rupture, and site erosion may result in the release of high dissolved and suspended solids loads to receiving waters (Dvorak et al. 1977, Barnthouse et al. 1977). For example, the collapse of a fly ash holding pond in 1967 released about $500 \times 10^{3} \mathrm{~m}^{3}$ of highly alkaline effluent to the Clinch River in less than one hour; this release represented about $40 \%$ of the river flow at the time and adversely affected about $145 \mathrm{~km}$ of river (Cairns et al. 1971). Table 4 contains water quality measurements for scrubber sludge and pond overflows.

Leachates from ash or scrubber sludge (Table 4) may also have adverse effects on water quality. Experimental ash leachate had excessive levels of boron, barium, chromium, mercury, and selenium, while experimental scrubber sludge leachate had excessive boron, barium, and selenium concentrations (Dvorak et al. 1977). The extent to which concentrations of these and other elements will be attenuated depends on such factors as soil type, depth of water table, pond sealing, dilution, and element mobility (Dvorak et al. 1977, Barnthouse et al. 1977). Leachate from a highly contaminated anaerobic landfill was nut renovated after passage through $12 \mathrm{~m}$ or more of sandy loam-sandy clay soil (Barnthouse et. al. 1977). Because overburden thicknesses are often less than $12 \mathrm{~m}$, and because overburden is of ten of large particle size, toxic elements can be expected to reach the water table easily. The soil type, bedrock, topography, and rainfall are site-specific; therefore, ground-water impacts will have 
Table 4. Representative water quality measurements for coal waste disposal effluents (all values except $\mathrm{pH}$ expressed as $\mathrm{mg} / 11$ ter [ppm])

\begin{tabular}{|c|c|c|c|c|}
\hline \multirow[b]{2}{*}{ Parameter } & \multicolumn{4}{|c|}{ Effluent } \\
\hline & $a$ & $b$ & c & $d$ \\
\hline  & $\begin{array}{l}0.02-513 \\
\text { negligible-0.14 } \\
0.005-0.06 \\
0.02-2.9 \\
0.0002-0.002 \\
0.0002-0.10 \\
0.008-0.015 \\
0.001-0.12 \\
100-300\end{array}$ & $\begin{array}{l}1.4-9.8 \\
0.01-0.05 \\
0.01-0.03 \\
0.02 \\
0.1 \\
0.02 \\
0.0015-0.0055 \\
0.05 \\
0.015 \\
0.01-0.02 \\
0-344\end{array}$ & $\begin{array}{l}520 \\
5 \\
80 \\
696 \\
1,095 \\
6.7 \\
70,780\end{array}$ & $\begin{array}{l}377 \\
5 \\
37 \\
484\end{array}$ \\
\hline
\end{tabular}

aAsh pond overflow. From Federal Energy Administration (19/1), lable IV-9.

bSimulated leachate from sludge fixated with Dravo "Calcilox." From Federal Energy Administration (1977), Table IV-13.

$C_{F}$ ixed scrubber sludge, as discharged to pond. From Federal Energy Administration (1977), Table IV-12.

$d_{f}$ ixed scrubber sludge pond overflow, discharge to water source. From Federal Energy Administration (1977), Table IV-12. 
to be generalized. Depending primarily on the soil composition and percolation rates and on bedrock composition and transmissivity, fly ash and scrubber sludge leachates may remain localized after introduction to the ground-water system. For example, percolation downward through a clay-rich, partially confining bed would considerably reduce the amount of contaminants introduced to an underlying aquifer. On the other hand, contaminated ground water in carbonate rocks may move over long distances through fractures, joints, fault planes, and other permeable zones (Barnthouse et al. 1977). Ground-water discharge points such as wells, streambeds at gaining reaches, and springs may be tens of kilometers away from the point at which the leachate entered the system (Quinlan 1976); the time of transit through such a carbonate rock system could be in terms of hours or several days.

The Committee on Health and Environmental Effects of Increased Coal Utilization singled out the issue of mobilization of trace elements from combustion wastes and resulting entrance into food chains as being of particular environmental importance (U.S. DHEW 1978). The committee stressed the need for better data on the mobilization potential of the trace elements. A similar need was found for better understanding of the toxicity and mobility of vanadium and thallium, so that the hazard potential of these two elements could be assessed (Barnthouse et al. 1977). For some of the trace elements (arsenic, cobalt, copper, iron, molybdenum, nickel, lead, scandium, selenium, uranfum, and $z \mid n c)$, discharge irito ash settling ponds at U.S. coal-fired power plants exceeds $10 \%$ of the natural nationwide weathering rate (measured as mass flow per unit time), with the rate for molybdenum, selenium, and uranium approximating the natural weathering rate (Klein et al. 1975). Mercury, cadmium, and lead are also of concern because the ir present levels of intake approach human health limits (Van Hook 1978). Because of their immobility in soil, zirconium and titanium (the latter is abundant in some western coals) were judged of concern only from pond leaks or failure (Barnthouse et a1. 1977). 
In addition to their trace element concentrations, combustion waste effluents are hazardous because of their elevated $\mathrm{pH}$ levels (Table 4). The hydrolys is of alkali and alkaline earth metals in ash settling basins may raise the $\mathrm{pH}$ to greater than 11 (Van Hook 1978). The reaction of lime-rich ash with water to produce calcium hydroxide raised the $\mathrm{pH}$ in the fly ash holding pond lagoon at the steam plant mentioned previously to 12.0 to 12.7 (Cairns et a1. 1971); the slurry's alkalinity was $90 \%$ hydroxide and $10 \%$ carbonate. The dissolved oxygen in the receiving water (the Clinch River) of the spill from that pond dropped as a result of decaying organic matter (Cairns et a1, 1971); calcium sulfite in scrubber sludge, with its high oxygen demand, may have the same effect (Dvorak et a1. 1977, U.S Environmental Protection Agency 1977a).

The high alkalinity of ash and scrubber sludge leachates would be somewhat buffered by downward percolation through acidic soil and overburden. The degree to which the alkaline leachate would be buffered depends on the nature and thickness of the overburden and on the composition of the bedrock (if any) above the ground-water table. Humic thick soils and pyritic organic colnys and shales would provide the most neutralization due to their inherent acidity. It is to be expected, however, that the $\mathrm{pH}$ of the leachates would not be reduced appreciably before entering the ground-water reservoir. The extent and rate of ground-water movement in the aquifer, as well as the $\mathrm{pH}$ of the ground water (which is likely to be slightly alkaline), will determine the impacts upon the water in storage. Aquifer degradation due to extreme alkalinity could occur at least locally. Leachate with a pH of 11 entering a calcium bicarbonate ground water, which is typical of carbonate aquifers, would precipitate calcium. In such an instance, the calcium could reduce the permeability of the aquifer by plugging so that ground-water movement could not occur.

Ash disposal impacts have been judged of greatest potential for Federal Regions VI, VIII, IX and X - the warm-water ecosystems of Region VI and the small-stream, cold-water fisheries of Regions VIII and IX were emphasized. Scrubber sludge impacts were seen as 
potentially hazardous in the coastal estuaries and warm-water systems of Region VI and in the high-quality, cold-water fisheries in the northern part of Region III (U.S. Environmental Protection Agency 1977 a).

\subsection{AQUATIC. BIOTA}

Small routine releases of effluents are common from waste treatment ponds; however, the major impacts that occur from this material result from accidents (pond failure or overflow and spillage during transport). Such events can create enormous stresses on receiving waters; the impact can be severe enough to extirpate virtually all organisms for some distance from the facility (Dvorak et al. 1977).

The severity of the effects induced by trace metal releases is dependent on the concentrations produced in the receiving waters, the $\mathrm{pH}$, the presence of other ions (e.g., calcium and magnesium), and the organisms exposed. The elements are essentially the same as those encountered in mine drainage and mine processing, but the relative quantities may be different. Section 1.4 contains a discussion of trace metal effects on biota.

Levels of $\mathrm{pH}$ of 11 or greater can be induced in receiving waters from waste effluents. In some cases, the effects produced may be minimal (especially if the change is episodic); many highly productive surface waters naturally obtain $\mathrm{pH}$ values of 10 or greater during active photosynthesis (Fogg 1975). Prolonged high pH levels or extremely high levels result in drastic drops in species diversity and productivity (Hynes 1971). Although a few organisms (chiefly a few algae and insect larvae) can survive at values as high as 13 (Hart and Fuller 1974, Brock 1966), fish seldom exist in waters continually above pH 10 (Bennett 1970). The physiological bases for intolerance of high $\mathrm{pH}$ levels are not well understood for many organisms. However, some of the factors include toxicity of $\mathrm{OH}^{-}$(by enzymatic inactivation or ion transport alteration) and the inability of some autotrophs to use $\mathrm{HCO}_{3}^{-}$or $\mathrm{CO}_{3}^{-}$in lieu of free $\mathrm{CO}_{2}$ in photosynthes is (1ittle free $\mathrm{CO}_{2}$ is available in surface waters at high $\mathrm{pH}$ levels) (Soeder and 
Stenge 1 1974).

A few constituents in the waste material (notably calcium sulfite) can create a high chemical oxygen demand in receiving waters. The resulting lowered oxygen levels can produce massive mortality of sensitive species (e.g., most sport fish) even if the discharge event is short-lived (National Academy of Sciences and National Academy of Engineering 1973). Low oxygen levels can also result in greater trace element availability (and, therefore, toxicity) and can favor the production, by reductive chemical processes, of other toxic compounds such as ammonia and hydrogen sulfide (National Academy of Sciences and National Academy of Engineering 1973).

The effects produced by high total dissolved solids and high total suspended solids concentrations are essentially the same as those discussed in Section 1.4 .

\subsection{WATER USE}

Ash disposal typically requires from 4 to $150 \mathrm{~m}^{3} /$ metric ton of ash (1000 to 40,000 gal/ton of ash) of water (Federal Energy Administration 1977). However, the greatest potential effects on water use are expected as a result of contamination of receiving waters (surface and ground). The dissolved and suspended constituents of effluents from coal ash and scrubber sludge may cause surface waters and groundwaters to exceed quality criteria for drinking water, livestock watering, irrigation, protection of aquatic biota, and other uses (Table 2). 


\section{REFERENCES}

Appalachian Regional Commission. 1969. Acid mine drainage in Appalachia. Washington, D.C.

Barnthouse, L.W., F. S. Sanders, and R. D. Roop. 1977. A preliminary assessment of the potential impacts on aquatic biota of trace elements in coal conversion solid waste. Presented at Symposium on Energy and Environmental Stress in Aquatic Systems. Savannah River Ecology Laboratory, November 2-4, 1977, Augusta, Georgia. Beamish, R. J., and H. H. Harvey. 1972. Acidification of the La Cloche Mountain Lakes, Ontario, and resulting fish mortalities. J. Fish. Res. Board Can. 29:1131-1143.

Bennett, G. W. 1970. Management of Lakes and Ponds. 2nd ed. Van Nostrand Reinhold Company, New York.

Brock, T. D. 1966. Principles of Microbial Ecology. Prentice-Hall, Englewood Cliffs, New Jersey.

Cairns, J., Jr., J. S. Crossman, K. L. Dickson, and E. E. Herricks. 1971. The recovery of damaged streams. ASB Bul1. 18(3):79-106.

Carter, R. P. , R. R. Hinchman, D. 0. Johnson, E. H. Dettman, A. J. Dvorak, D. Grahn, B. B. Green, J. P. Harper, J. R. Lafevers, R. M. Miller, R. D. O1sen, S. H. O'Connor, J. P. Schubert, A. A. Sobek, and S. D. Zellmer. 1977. Reclamation (Revised draft). Prepared for the Special Committee to Study Health and Environmental Effects of Increased Coal Production. Coal Extraction and Land Reclamation Group, Argonne National Laboratory, Argonne, Illino is.

Caruccio, F. T. 1975. Estimating the acid potential of coal mine refuse. IN M. J. Chadwick and G. T. Goodman (eds.), Ecology of Resource Degradation and Renewal. John Wi ley, New York.

Cogbi11, C. V., and G. E. Likens. 1974. Acid precipitation in the northeastern United States. Water Resour. Res. 10:1133-1137.

Cronan, C. S., and C. L. Schofield. 1979. Aluminum leaching response to acid precipitation: Effects on high-elevation watersheds in the Northeast. Science 204:304-306. 
Curtis, W. R. 1977. Surface mining and the flood of April, 1977. Forest Service Research Note NE-248. U.S. Department of Agriculture, Upper Darby, Pennsylvania.

Cushman, R. M., S. G. Hildebrand, R. H. Strand, and R. M. Anderson. 1977. The toxicity of 35 trace elements in coal to freshwater biota: A data base with automated retrieval capabilities. ORNL/TM-5793. Oak Ridge National Laboratory, Oak Ridge, Tennessee. Davis, E. C., and W. J. Boegly, Jr. 1978. A review of the literature on leachates from coal storage piles. ORNL/TM-6186. Oak Ridge National Laboratory, Oak Ridge, Tennessee.

Dávís, R. M., L. G. Berry, D. J. Bjornstad, F. D. Boercker, J. E. Dobson W. R. Emanuel, R. B. Honea, D. D. Huff, J. R. Hyndman, C. R. Kerley, J. T. Kitchings, J. M. Klopatek, B. D. Murphy, D. C. Parzyck, R. J. Raridon, H. H. Shugart, and D. C. West. 1978. National Coal Utilization Assessment. A preliminary assessment of coal utilization in the South. ORNL/TM-6122. Oak Ridge National Laboratory, Oak Ridge, Tennessee.

Doyle, W. S. 1976. Strip Mining of Coal: Environmental Solutions. Noyes Data Corporation, Park Ridge, New Jersey.

Dugan, P. R. 1972. Biochemical Ecology of Water Pollution. Plenum Press, New York.

Dvorak, A. J., C. D. Bruwri, E. H. Dettman, R. A. Hinchman, J. D. Jastrow, F. C. Kornegay, C. R. LaFrance, B. G. Lewis, R. T. Lundy, R. D. 01sen, J. I. Parker, E. D. Pentecost, J. L, Saguinsin, and W. S. Viniknur.. 1977. The environmental effects of using coal for generating electricity. NUREG-0252. Argonne National Laboratory, Argonne, Illinois.

Federal Energy Administration. 1977. Coal Conversion Program, Energy Supply, and Environmental Coordination Act (as Amended), Section 2. Final Revised Environmental Impact Statement. FES-77-3. Washington, D. C.

Fugg, G. E. 1975. Algal Cultures and Phytoplankton Ecology, 2nd ed. University of Wisconsin Press, Madison.

Fogg, G. E., W. D. P. Stewart, P. Fay, and A. E. Walsby. 1973. The Blue-green Algae. Academic Press, New York. 
Galloway, J. N., G. E. Likens, and E. S. Edgerton. 1976. Acid precipitation in the northeastern United States: $\mathrm{pH}$ and acidity. Science 194:722-724.

Glass, N. R. (ed.). 1977. Environmental effects of increased coal utilization: Ecological effects of gaseous emissions from coal combustion. Office of Health and Ecological Effects, Office of Research and Development, Washington, D. C.

Goldman, C. R. 1972. The role of minor nutrients in limiting the productivity of aquatic ecosystems. pp. 21-33. IN G. E. Likens (ed.), Nutrients and Eutrophication, Special Symposia, Vol. 1. American Society of Limnology and Oceanography, Allen Press, Lawrence, Kansas.

Habegger, L. J., A. J. Dvorak, L. J. Hoover, G. Krohm, J. Cavallo, C. Dux, W. Pelletier, R. Bright, P. Dauzvardis, K. Brubaker, D. Kellermeyer, M. Snider, R. Sprunger, J. Vankuiken, R. Lundy, S. Y. Chiu, S. C. Chay, J. Gasper, J. Hoffman, K. Holub, D. Smithyman, and C. Comer. 1977. A preliminary assessment of the health and environmental effects of coal utilization in the Midwest. Vol. 1. Energy scenarios, technology characterizations, air and water resource impacts, and health effects (Draft). Argonne National Laboratory, Argonne, Illinois: Hart, C. W., Jr., and S. L. H. Fuller. 1974. Pollution Ecology of Freshwater Invertebrates. Academic Press, New York.

Henriksen, A., and R. F. Wright. 1978. Concentrations of heavy metals in small Norwegian lakes. Water Res. 12:101-112.

Hill, R. D., and E. R. Bates. 1977. Acid mine drainage and subsidence (Draft). Prepared for the President's Committee on the Health and Environmental Effects of Increased Coal Utilization. Industrial Environmental Research Laboratory, U.S. Environmental Protection Agency, Cincinnati, Ohio.

Hutchinson, G. E. 1967. A Treatise On Limnology. Vol. II. Introduction to Lake Biology and the Limnoplankton. John Wiley and Sons, Inc., New York. 
Hynes, H. B. N. 1971. The Biology of Polluted Waters. University of Toronto Press, Toronto.

Hynes, H. B. N. 1972. The Ecology of Running Waters. University of Toronto Press, Toronto.

Kash, D. E., M. D. Devine, t. J. Wi lbanks, A. R. Brosz, and R. D. Speer. 1977. The Impacts of Accelerated Coal Utilization (Draft). Science and Public Policy Program, University of Ok lahoma, Norman, Ok lahoma.

Keefer, W. R., and R. F. Hadley, 1976. Land and natural resource information and some pulential environmental effer.ts of surface mining of coal in the Gillette area, Wyoming. Geologicdl survey Circular 743. U.S. Geological Survey, Alexandria, Virginia.

Kilpatrick, F. A., and G. H. Davis. 1976. Water demand related to increased coal utilization in the United States. Prepared by U.S. Geological Survey, Reston, Virginia.

King, D. L., J. J. Simmler, C. S. Decker, and C. W. Ogg. 1974. Acid strip mine lake recovery. J. Water Pollut. Control Fed. 45:2301-2315.

Klein, D. H., A. W. Andren, and N. E. Bulton. 1975. Trace element discharges from coal combustion for power production. Water Air Sol1 Pullut. 5:71-77.

Klein, D. H., and P. Russe11. 1973. Heavy metals: Fallout around a power plant. Environ. Sci. Technol. 7(4):357-358.

Kopp. J. F., and R. C. Kroner. 1967. Tracing water pollution with an emission speclrograph. J. Water Poliut. Controi Fed. 39:1059-1668.

Lind, 0., and R. S. Campbe11. 1970. Community metabolism in acid and alkaline stripmine lakes. Trans. Am. Fish. Soc. 99:577-582.

Martin, J. F. 1974a. Coal refuse disposal in the Eastern United States. U.S. Environmental Protection Agency, National Environmental Research Center, Cincinnati, Ohio.

Martin, J. F. 1974b. Quality of effluents from coal refuse piles. Presented at the First Symposium on Mine and Preparation Plant Refuse Disposal, October 22, 1974, Louisville, Kentucky. 
Martin, J. F. 1976. The impact of coal refuse disposal on water quality. Mining pollution control report. U.S. Environmental Protection Agency, Industrial Environmental Research Laboratory, Cincinnati, Ohio.

Minck ley, W. L., and J. E. Deacon. 1968. Southwestern fishes and the enigma of "endangered species." Science 159:1424-1432.

Minear, R. A., and B. A. Tschantz. 1976. The effect of coal surface mining on the water quality of mountain drainage bas in streams. J. Water Pollut. Control Fed. 48(11):2549-2569.

Moss, B. 1973. The influence of environmental factors on the distribution of freshwater algae: An experimental study. II. The role of $\mathrm{pH}$ and the carbon dioxide-bicarbonate system. J. Ecol. 61:157-177.

National Academy of Sciences and National Academy of Engineering. 1973. Water quality criteria, 1972. EPA-R-73-033. Environmental Protection Agency, Washington, D. C.

Office of Surface Mining Reclamation and Enforcement. 1979. Surface coal mining reclamation operations. Permanent regulatory program. Fed. Regist. 43:15311-15463.

Quinlan, J. F. 1976. Hydrology of the turnhole spring groundwater bas in and vicinity. Management Report No. 11. Uplands Field Research Laboratory, Mamoth Cave, Kentuck.y.

Roback, S. S., and J. W. Richardson. 1969. The effects of acid mine drainage on aquatic insects. Proc. Acad. Nat. Sci. Philadelphia 121:81-107.

Russell-Hunter, W. D. 1970. Aquatic Productivity. MacMillan Publishing Co., New York.

Sculthorpe, C. D. 1967. The Biology of Aquatic Vascular Plants. Edward Arnold (Publishers), Ltd., London.

Smith, R. W., and D. G. Frey. 1971. Acid mine pollution effects on lake biology. Water Pollut. Control Res. Series 18050 EEC 12/71. Enviromental Protection Agency, Washington, D. C.

Soeder, C. J., and E. Stengel. 1974. Physico-chemical factors affecting metabolism and growth rate. pp. 714-740. IN W. D. P. Stewart (ed.), Algal Physiology and Biochemistry. University of California Press, Berkeley. 
Tomkiewicz, S. M., Jr., and W. A. Dunson. 1977. Aquatic insect diversity and biomass in a stream marginally polluted by acid strip mine drainage. Water Res. 11:397-402.

Trelease, F. J., III, and R. D. Burman. 1975. Water needs for reestablishing vegetation on mined lands in the eastern Wyoming Powder River Basin. pp. 163-172. IN Irrigation and Drainage in an Age of Competition for Resources. Proceedings of a Specialty Conference Conducted by the Irrigation and Drainage Division of the American Society of Civil Engineers, American Society of Civil Engineers, New York. 502 pp.

U.S. Army Corps of Engineers. 1974. The National Strip Mine Study. Vo 1. 1: Summary Report (Draft). Washington, D. C.

U.S. Department of Energy. 1979. Final environmental impact statement, Fuel Use Act. D0E/EIS-0038. Economic Regulatory Administration, Washington, D.C.

U.S. Department of Health, Education, and We If are (DHEW). 1978. Health and environmental effects of increased coal utilization. Advisory Committee report. Fed. Regist. 43:2229.

U.S. Environmental Protection Agency. 1974. Part 423 - Steam electric power generating point source category. Fed. Regist. 39:36198.

U.S. Environmental Protection Agency. 1975. National interim.primary drinking water regulations. Fed. Regist. 40:248.

U.S. Environmental Protection Agency. 1976. Quality criteria for water. EPA-440/9-76-023. Washington, D. C.

U.S. Environmental Protection Agency. 1977 a. Health and environmental impacts of increased generation of coal ash and FGD sludges. Report to the Committee on Health and Ecological Effects of Increased Coal Utilization. Office of Kesearch and Developmenl, Office of Energy Minerals and Industry, Washington, D. C.

U.S. Environmental Protection Agency. 1977b. National secondary drinking water proposed regulations. Fed. Regist. 42:62. 
Van Hook, R. I. 1978. Potential health and environmental effects of trace elements and radionuclides from increased coal utilization. ORNL-5367. Oak Ridge National Laboratory, Oak Ridge, Tennessee. 


\section{THIS PAGE \\ WAS INTENTIONALLY \\ LEFT BLANK}


ORNL/TM-7152

INTERNAL DISTRIBUTION


53-62. M. S. Moran
63. P. J. Mulholl and
64. D. C. Parzyck
65. R. M. Reed
66. D. E. Reichle
67. R. D. Roop
68. T. H. Row
69. M. S. Salk
70. A. D. Shepherd
71. T. Tamura
72. V. R. Tolbert
73. E. K. Triege?
74. W. Van Winkle
75. A. P. Watson
76. H. E. Zittel
77. ESD Library
78. Ecological Sciences Inf ormation Center
79. Energy \& Environmental
80-81. Central Research Library
82-83. Laboratory Records Dept. 84. Laboratory Records, ORNL-RC 85. ORNL Y-12 Technical Library 86. ORNL Patent Office

\section{EXTERNAL DISTRIBUTION}

87. Office of Assistant Manager, Energy Research and Development, DOE-ORO

88. Appalachian Regional Commission, 1666 Connecticut Ave., NW, Washington, DC 20235

89. James Bartis, Director, Planning and Systems Engineering Division, Fossil Energy Programs, U.S. Department of Energy, Washington, DC 20545

90. Robert W. Brocksen, Electric Power Research Institute, 3412 Hillview Ave., P.0. Box 10412, Palo Alto, CA 94303

91. Lynda L. Brothers, Acting Deptuty Assistant Secretary for Environment, U.S. Department of Energy, Washington, DC 20545

92. Michael Carosella, Economic Regulatory Administration, U.S. Department of Energy, Washington, DC 20545

93. Ralph P. Carter, Director, Coal Extraction and Reclamation Programs, Energy and Environmental Systems Division, Argonne National Laboratory, 9700 South Cass Ave., Argonne, IL 60439 
94. Ruth Clusen, Assistant Secretary for Environment, U.S. Department of Energy, Washington, DC 20545

95. William J. Coppoc, Chairman, Texaco, Inc., PO Box 509, Beacon, NY 12508

96. Roger C. Dahlman, Office of Carbon Dioxide Effects, U.S. Department of Energy, Washington, DC 20545

97. Anthony Dammer, Division of NEPA Affairs, U.S. Department of Energy, Forrestal B1dg., Washington, DC 20545

98. Robert Davies, Economic Regulatory Administration, U.S. Department of Energy, Washington, DC 20545

99. Dr. Stanley Nelson Davis, Head, Department of Hydrology and Water Resources, University of Arizona, Tucson, AZ 85721

100. Director, Office of Surface Mining, Department of the Interior, Washington, DC 20240

101. Anthony J. Dvorak, Division of Environmental Impacts Studics, Bldg. 10, Argonne National Laboratory, 9700 S. Cass Ave., Argonne, IL 60439

102. Steven Ferguson, Economic Regulatory Administration, U.S. Department of Energy, Washington, DC 20545

103. Thomas G. Frangos, Office of Environmental Compliance and Overview, U.S. Department of Energy, Washington, DC 20545

104. Steven Frank, Economic Regulatory Administration, U.S. Department of Energy, Washington, DC 20545

105. Ralph Franklin, Office of Health and Environmental Research, U. S. Department of Energy, Washington DC 20545

106. Dr. Robert M. Garrels, Department of Geological Sciences, Northwestern University, Evanston, IL 60201

107. Marsha Goldberg, Economic Regulatory Administration, U. S. Department of Energy, Washington, DC 20545

108. Larry P. Gough, U.S.G.S., Branch of Regional Geochemistry, Denver Federal Center, Denver, CO 80225

109. Philip F. Gustatson, Uivision of Environmental Impact Studies, Argonne National Laboratory, 9700 South Cass Ave., Argonne, IL 60439

110. Carol Hanlon, Economic Regulatory Administration, U. S. Department of Energy, Washington, DC 20545

111. Ronnie J. Haynes, U.S. Fish and Wildlife Service, Richard B. Russell Federal Building, 75 Spring St., SW, Atlanta, GA 30303

112. James Johnson, Planning and Systems Engineering Division, Fossil Energy Programs, U. S. Department of Energy, Washington, DC 20545

113. Dr. George H. Lauff, Director, W. K. Kellogg Biological Station, Michigan State University, Hickory Corners, Michigan 49060

114. Dr. Simon A. Levin, Institute of Animal Resource Ecology, The University of British Columbia, 2075 Wesbrook Mall, Vancouver, B.C., CANADA V6T 1 W5

115. Robert Lewis, Office of Health and Environmental Research, U. S. Department of Energy, Washington DC 20545 
116. Dilip R. Limaye, Synergic Resources Corporation, 1 Bala-Cynwyd Plaza Suite 434, Bala-Cynwyd, PA 19004

117. Mike Marshall, Program Officer/Energy, Ozarks Regional Commission, Suite 109, Evergreen Place, 1100 North University, Little Rock, AR 72207

118. Helen McCammon, Office of Health and Environmental Research, U. S. Department of Energy, Washington, DC 20545

119. John Nardella, Planning and Systems Engineering Division, Fossil Energy Programs, U. S. Department of Energy, Washington, DC 20545

120. Linda Nesenholtz, Economic Regulatory Administration, Department of Energy, Washington, DC 20545

121. William S. Osburn, Office of Health and Environmental Research, U.S. Department of Energy, Washington, DC 20545

122. Regional Director, Office of Surface Mining, Region I, Thomas Hill Building, 950 Kanawha Boulevard East, Charleston, WV 25301

123. Regional Director, Office of Surface Mining, Region II, Northshore Building 2, 1111 Northshore Drive, Knoxville, TN 37902

124. Regional Director, Office of Surface Mining, Region III, Federal Building and Courthouse, Ohio and Pennsylvania Streets, Indianapolis, IN 46205

125. Regional Director, Office of Surface Mining, Region IV, 601 East 12th Street, Kansas City, MO 64116

126. Regional Director, Office of Surface Mining, Region V, 01d Post Office Downtown, 1823 Stout Street, Denver, C0 80202

127. Dr. Paul G. Risser, Department of Botany and Microbiology, University of Okiahoma, Norman, OK 73019

128. Walter A. Romanek, Economic Regulatory Administration, U.S. Department of Energy, Washington, DC 20545

129. David Rubin, Economic Regulatory Administration, U.S. Department of Energy, Washington, DC 20545

130. Robert J. Stern, Director, Division of NEPA Affairs, U.S. Department of Energy, G064 Forrestal Bldg., Washington, DC 20545

131. Dr. Richard H. Waring, Department of Forest Science, Oregon State University, Corvallis, OR 97331

132. James G. Wiener, National Fishery Research Laboratory, P.0. Box 818, 2630 Fanta Reed Road, LaCrosse, WI 54601

133. Lila Williams, U.S. Department of Energy, Region VI, P.0. Box 35228, Dallas, TX 75235

134. Jerry F. Wing, U.S. Department of Energy, Oak Ridge Operations, P.O. Box E, Oak Ridge, TN 37830

135. Mac Woodward, Arkansas State and Local Program Officer, U.S. Department of Energy, 3508 Federal Building, Little Rock, AR 72201

136-162. Technical Information Center, Oak Ridge, TN 37830 